\title{
Earthworms Building Up Soil Microbiota, a Review
}

\author{
Regina M. Medina-Sauza ${ }^{1 \dagger}$, Marycruz Álvarez-Jiménez ${ }^{2,3 t}$, Alix Delhal ${ }^{4}$, \\ Frédérique Reverchon ${ }^{3 *}$, Manuel Blouin ${ }^{4}$, José A. Guerrero-Analco ${ }^{3}$, Carlos R. Cerdán ${ }^{2}$, \\ Roger Guevara ${ }^{5}$, Luc Villain ${ }^{6}$ and Isabelle Barois ${ }^{1 *}$
}

\begin{abstract}
${ }^{1}$ Red de Ecología Funcional, Instituto de Ecología A.C., Xalapa, Mexico, ${ }^{2}$ Facultad de Ciencias Agrícolas, Universidad Veracruzana, Xalapa, Mexico, ${ }^{3}$ Red de Estudios Moleculares Avanzados, Instituto de Ecología A.C., Xalapa, Mexico, ${ }^{4}$ Agroécologie, AgroSup Dijon, CNRS, INRA, University Bourgogne Franche-Comté, Dijon, France, ${ }^{5}$ Red de Biología Evolutiva, Instituto de Ecología A.C., Xalapa, Mexico, ${ }^{6}$ UMR-Interactions Plantes Microorganismes Environnement, Institut de Recherche pour le Développement (IRD) and Centre de Coopération Internationale en Recherche Agronomique pour le Développement (CIRAD), Montpellier, France
\end{abstract}

\section{OPEN ACCESS}

Edited by:

Juan José Jiménez, Consejo Superior de Investigaciones Científicas, Spain

Reviewed by:

Alexei V. Tiunov,

Severtsov Institute of Ecology and Evolution (RAS), Russia

Claire Le Bayon,

Université de Neuchâtel, Switzerland

*Correspondence:

Frédérique Reverchon frederique.reverchon@inecol.mx Isabelle Barois

isabelle.barois@inecol.mx

tThese authors have contributed equally to this work as co-first authors

Specialty section:

This article was submitted to Soil Processes,

a section of the journal

Frontiers in Environmental Science

Received: 29 January 2019

Accepted: 21 May 2019

Published: 07 June 2019

Citation:

Medina-Sauza RM Álvarez-Jiménez M, Delhal A,

Reverchon F, Blouin $M$,

Guerrero-Analco JA, Cerdán CR,

Guevara $R$, Villain $L$ and Barois I (2019) Earthworms Building Up Soil

Microbiota, a Review.

Front. Environ. Sci. 7:81.

doi: 10.3389/fenvs.2019.00081
The positive effect of earthworms on soil processes and plant growth has been extensively documented. The capacity of earthworms to decompose organic matter has been attributed to the microbial communities that inhabit their digestive track or the structures they build, which in turn contribute to make up the drilosphere, a hotspot for microbial activity. However, how earthworms modify the structure of soil microbial communities and how these changes affect soil microbial processes is still unclear. Do earthworms reduce microbial abundance and activity because they feed on microorganisms or do they select and stimulate specific microbial groups? We hypothesise that "the effect of earthworms on nutrient cycling and plant growth is not only a direct effect but is mainly mediated indirectly, via modifications of the microbial community." The objective of this review is to synthesize the existing literature concerning the influence of earthworms on the structure and function of soil microbial communities, as well as to understand how earthworm-induced changes in the soil microbiota would in turn impact soil processes, particularly those occurring in the rhizosphere and involved in plant growth and health. Recent reports have shown that specific bacterial groups consistently increase in soils where earthworms are present, regardless of the earthworm functional group. The extent of this increase seems to be dependent upon the type of substrate under study. Our synthesis also reveals that endogeic and anecic earthworms regularly induce an increase in soil nutrients, whilst this positive effect is not as evident in the presence of epigeic earthworms. The effect of earthworms on nutrient cycling has been further investigated with microbial functional genes, although existing reports largely focus on nitrogen cycling. Earthworms seem to enhance denitrification, most likely through the increase in organic compounds due to organic matter decomposition. By enhancing soil nutrient availability, earthworms indirectly promote plant growth, which has also been attributed to the induction of signal molecules. However, no experiment to date has been able to prove a direct causal relationship between specific signal molecules, earthworms and plant growth promotion. Finally, we propose a framework for earthworm-microbiota interactions and recommend further research.

Keywords: soil nutrient hotspots, interactions, soil biotransformation, signal molecules, drilosphere, microbiome 


\section{INTRODUCTION}

Earthworms are considered as ecosystem engineers that play an important role in shaping soil structure and cycling nutrients (Blouin et al., 2013). Earthworms promote litter decomposition, nitrogen $(\mathrm{N})$ mineralisation and water infiltration, as a result of their feeding and burrowing habits (Baker, 2007), and therefore deeply affect soil properties (Hättenschwiler and Gasser, 2005). They also play a crucial role in the provision of soil ecosystem services (Lavelle et al., 2016). The soil volume directly influenced by earthworms, known as the drilosphere (Bouché, 1977; Lavelle, 2002), is an important functional region of the soil, made by the earthworm community and the structures it creates: middens, burrows, tunnels, and casts. Earthworms are thus builders of habitats for other organisms, which establishes them as physical or allogenic engineers (Jones et al., 1994; Lavelle et al., 1997, 2016). Besides, these building activities constitute an input of organic matter to the soil and a pathway for the stabilization of soil organic carbon (Corg) through the formation of organomineral aggregates (Deeb et al., 2017). This enrichment in organic matter mainly results from earthworm food choice (Curry and Schmidt, 2007), its digestion and excretion of intestinal or cutaneous mucus that can be cementing (Shipitalo and Le Bayon, 2004) or used as an energy source (Lavelle et al., 1995). Therefore, in addition to shaping soil structure, earthworms also have an important impact on soil organic matter dynamics and microorganisms in their gut, casts and drilosphere (Andriuzzi et al., 2016) and are also identified as biochemical (Lavelle et al., 2016) or autogenic ecosystem engineers (Lawton and Jones, 1995).

Earthworms are divided into three main functional groups or ecological categories, which determines how they influence the soil compartment and its microbial communities (Thakuria et al., 2010): (1) epigeic earthworms live on the soil surface and feed from the litter; (2) endogeic earthworms live in the soil and produce horizontal tunnels, while feeding on mineral soil and partially decomposed material, being then geophagous; (3) anecic earthworms produce permanent vertical burrows and feed on the litter that they drag into their burrows to be pre-decomposed by microorganisms, while depositing their casts at the burrow entrance (Bouché, 1977; Lavelle, 1981; Lee, 1985).

Earthworms are considered as key ecological mediators that have the capacity to affect soil functions and microbial activities (Binet et al., 1998; Lavelle et al., 2016), by producing an energy-rich mucus that activates microorganisms through a priming effect (Jenkinson, 1966) and signal molecules that have hormone-like effects and influence plant gene expression (PugaFreitas and Blouin, 2015). The mutualistic interaction existing between earthworms and the soil microbiota has been named the "Sleeping Beauty Paradox" (Lavelle et al., 1995; Brown et al., 2000), where dormant soil microorganisms, awaiting suitable environmental conditions are activated by the kiss of the earthworm made of easily assimilable glycoproteins present in the drilosphere in the form of intestinal or cutaneous mucus as already mentioned. This triggers the acceleration of microbial processes for a short period of time ("hot moment") and in a limited soil space ("hot spot"), at the microscale of a biopore or aggregate (Kuzyakov and Blagodatskaya, 2015) which reverberates on a larger scale, at the drilosphere and soil levels (Brown et al., 2000; Hoang et al., 2016; Lipiec et al., 2016).

Earthworms have a direct and important effect on the soil microbiota through their nutrition. This effect may depend on their food preference, selection, food ingestion rate, digestion and assimilation, as mentioned by Curry and Schmidt (2007). Earthworms can digest microorganisms (Brown, 1995; ChapuisLardy et al., 2010) thereby decreasing microbial biomass, especially that of fungi (Shan et al., 2013). They may also select or stimulate soil microbes (Khomyakov et al., 2007; Nechitaylo et al., 2010) which help them digest the soil organic matter, since the earthworm gut often lacks the sufficient enzymes to do so (Lattaud et al., 1997, 1998; Fujii et al., 2012). This process may enrich the soil in certain bacterial taxa, for example in bacteria able to decompose the organic matter that earthworms feed on or in denitrifying bacteria able to survive in the reduced oxygen conditions of the earthworm gut (Drake and Horn, 2007; Hong et al., 2011).

The physiology, morphology and behaviour of earthworms is essential to understand their effect on soil functions (Figure 1, arrow 1). However, there is increasing evidence that the effect of earthworms on soil functions may be mediated through soil microbial communities (Figure 1, arrow 2). It is yet not clear how the different ecological groups may promote or select soil microorganisms and there are many contradictory results concerning the effect of earthworms on soil microbial communities (Byzov et al., 2015). However, the drilosphere is generally acknowledged as being a soil hotspot with a positive effect on ecosystem functions such as nutrient cycling and plant growth (Brown et al., 1999; Scheu, 2003; Van Groenigen et al., 2014).

Considering that the involvement of microorganisms in these functions is fundamental, it is therefore necessary to consider microbial communities and how they are influenced by earthworms in order to understand and predict the effect of earthworms on ecosystem functions. It is our hypothesis that "the effect of earthworms on nutrient cycling and plant growth is not only a direct effect but is mainly mediated indirectly, via modifications of the microbial community" (Figure 1). Thus, the objectives of this review are two. The first is to determine whether some patterns can be drawn from the existing literature regarding the effect of the different earthworm functional groups (epigeic, endogeic, and anecic) on the abundance, structure and diversity of soil microorganisms (bacteria, archae, and fungi) at the different sites (earthworm gut, casts, burrows, bulk soil, rhizophere, others). The analytical methods used are also considered [Gram $+/-$, fingerprinting, phospholipid fatty acids (PLFA), sequencing]. The second is to establish the impact of earthworms on microbial processes involved in nutrient cycling, on the production of signal molecules and as a consequence, on plant growth promotion. The selected literature was mainly chosen from studies that deal with earthworms and microbial (microorganisms, microbiome) interactions and nutrient cycling (Nitrogen, Phosphorus) between 1980 and 2018; however, for 


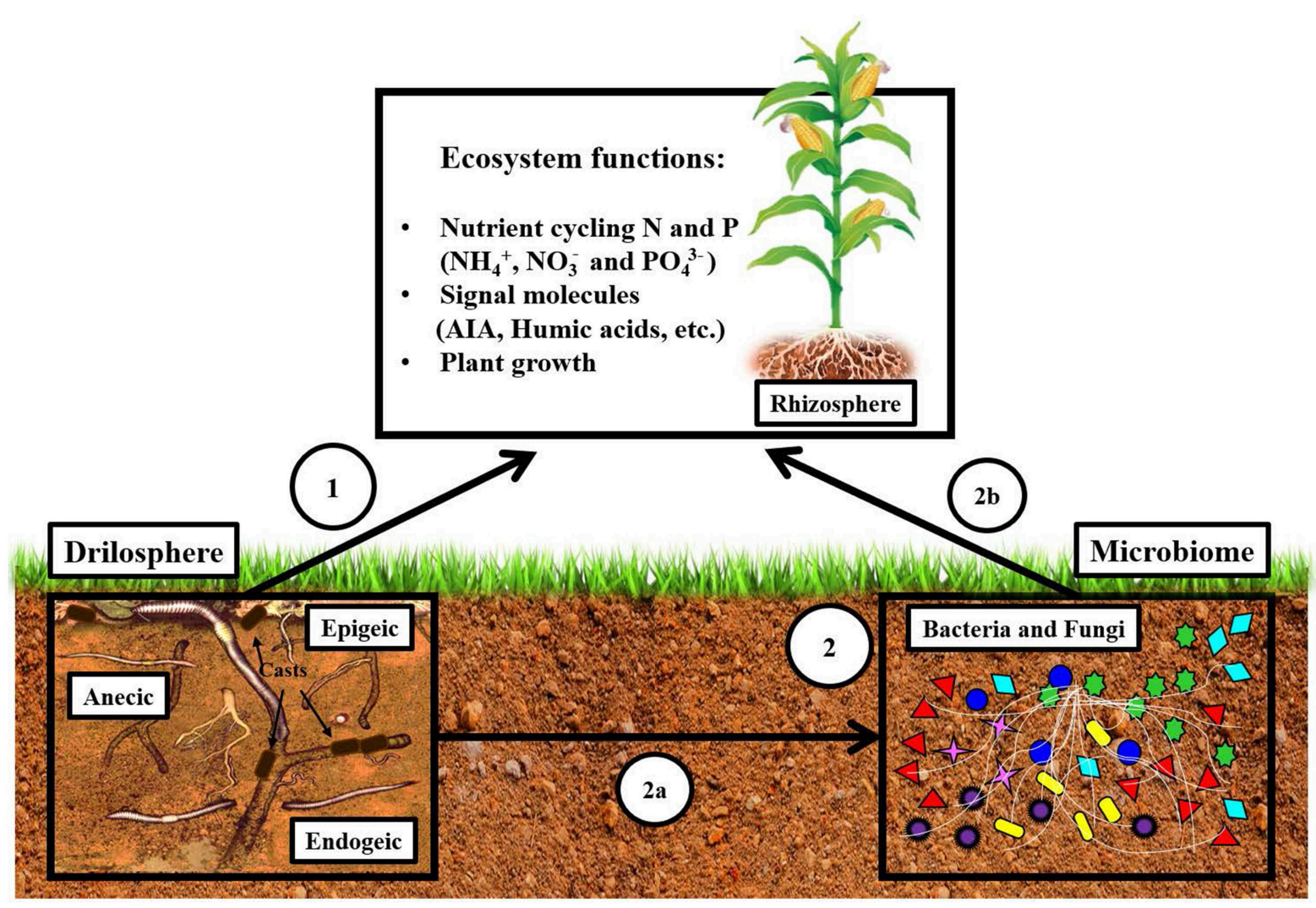

FIGURE 1 | Hypothesis: effect of earthworms on nutrient cycling and plant growth is not only a direct effect but it is mainly mediated indirectly by microorganisms. The impact of earthworms is direct (1), or indirect, through the stimulation of microorganisms (2). By modifying microbial communities (2a), earthworms impact the way bacteria are influencing ecosystem functions (2b). This figure aims at illustrating the fact that indirect effects are as important as direct ones.

specific topics we used the Web of Science (WOS) with precise keywords (see Figures 4-6 legend).

Finally, we propose a framework for earthworm-soil microbiome interactions and recommend further research to be directed towards elucidating the microbial processes occurring in the drilosphere.

\section{THE IMPACT OF EARTHWORMS ON THE ABUNDANCE AND ACTIVITY OF SOIL MICROORGANISMS}

The effect of earthworms on soil microbial communities is critical as they are one of the most important fauna group in soils, in terms of number and biomass (Blouin et al., 2013). Besides, earthworms can have a very high rate of substrate or soil ingestion. Epigeic earthworms can ingest 3-50 mg (dry matter) of dung or any other kind of litter per gram of earthworm per day and the geophagous worms 200-6,700 mg (dry matter) of soil per gram of earthworm per day (Curry and Schmidt, 2007). In this section, we will synthesize the available information regarding how earthworms influence the abundance or activity of soil microorganisms, depending on their functional groups.

\section{The Epigeics}

The consequences of the presence of epigeic earthworms on soil microbial abundance are variable (Figure 2). The literature shows that they can provoke either a decrease or an increase in microbial biomass. Less frequently, reports show that the number of microorganisms remains unaffected by their action. Most studies found in the literature are performed under artificial laboratory conditions and use epigeic earthworm species Eisenia andrei and E. fetida, grown in different feedstocks (dungs, agriculture by-products and mixtures of organic matter and soil). These studies report that these species induce an increase of the microbial biomass in the transformed substrate which is made up mainly of casts, although the magnitude of this effect varies through different time scales. The activity and the numbers of microorganisms have a peak at the beginning of the digestion which lasts at the most a few hours in the gut (Brown et al., 2000) and a bit longer in the fresh casts, these sites being "hot spots and moments." After some months (3-4) there is a decrease in microbial activity and numbers in the casts or vermicompost and then there is a stabilization of both (Yakushev et al., 2009) Koubová et al. (2015) indicated that microbial biomass measured by PLFA was 2 -fold greater in the earthworm gut than in the non-ingested substrate and that biomass was also higher in casts than in the surrounding substrate, although this increase was 


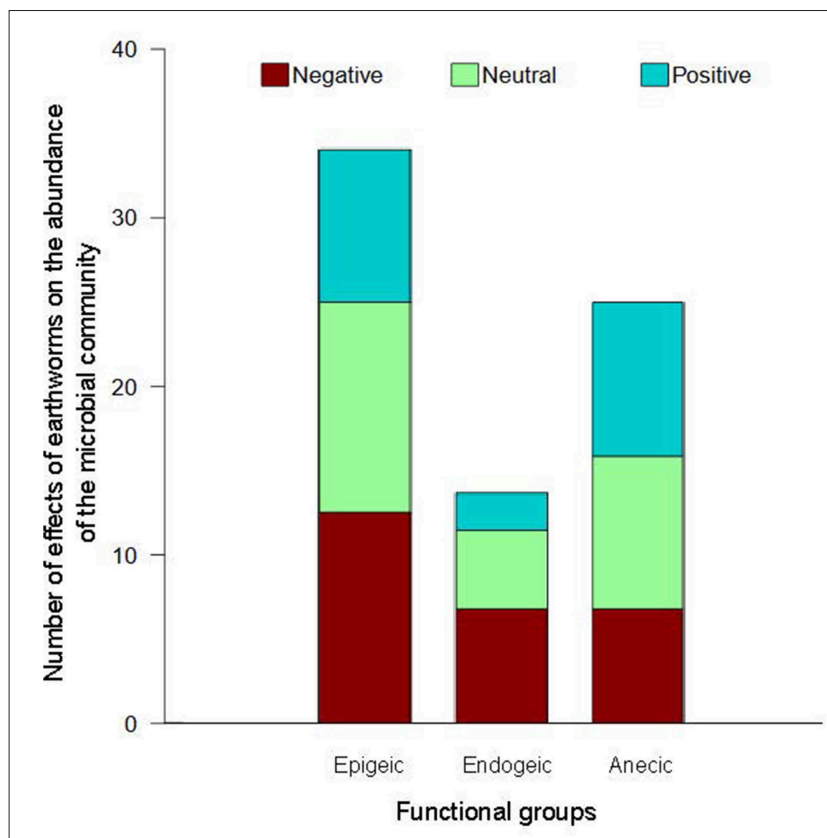

FIGURE 2 | The effect of earthworms on microbial abundance depending on their functional group. Thirty-one studies from 1986 to 2018 were considered. All the studies were carried out in controlled conditions with the exception of one (Stromberger et al., 2012). Five articles were from tropical regions and all the others from temperate regions. The microbial abundance was measured in five gut contents, 11 casts, 12 vermicomposts, 11 soils, four burrows, and one midden from the different studies. Some studies presented results from more than one earthworm species, ecological category and site measurement.

less important than in the gut. Yakushev et al. (2009) showed an increase in microbial biomass of 2.7 times in the casts of $E$. fetida and evidenced that microbial growth in a period of $9 \mathrm{~h}$ was 124 times higher in vermicompost than in compost. In a mixture of pig manure and soil, the microbial biomass was 1.3 times higher in the presence of earthworms (Aira et al., 2007). Toyota and Kimura (2000) found that bacterial biomass, evaluated by counting colony forming units (CFU), increased from $3.2 \times 10^{4}$ $\mathrm{CFU} \mathrm{g}{ }^{-1}$ in composted farmyard manure to $1.3 \times 10^{7} \mathrm{CFU} \mathrm{g}^{-1}$ in vermicompost with $E$. fetida.

Although other studies show that epigeic earthworms do not have any impact on microbial abundance in the soil, this effect seems to be dependent upon the kind of feedstock assessed. On leaf compost from alder, willow and birch with a $C / N=19.2$, the presence of $E$. fetida/E. andrei induced a great increase in the number of microorganisms whereas vermicompost made from cattle manure $(C / N=15.4)$ did not present any differences with its respective control compost without earthworms $(\mathrm{C} / \mathrm{N}$ $=16.5$ ) (Yakushev et al., 2009). Sheehan et al. (2008) using mesocosms showed that, in addition to the influence of the food supply, the effect of epigeic earthworms on the abundance of microorganisms also depends on the soil layer under study and reported a larger increase in microbial biomass in the upper layers $(0-7 \mathrm{~cm})$ than in the deeper ones $(7-14 \mathrm{~cm})$.

On the other hand, several studies demonstrated that epigeic worms can decrease microbial biomass in their casts or in the substrate they live on (Figure 2). Through measurements of total PLFA, Gómez-Brandón et al. (2012) and Aira et al. (2002, 2006) found less microbial biomass in E. andrei vermicompost from grape bagasse and in E. fetida and Eudrilus eugeniae vermicompost from pig manure than in substrates without earthworms, although this effect seemed to depend upon the earthworm density (Aira et al., 2002). Overall, literature findings show that no clear effect of epigeic earthworms can be detected in microbial biomass, nor on the growth rate of microbial populations. Discrepancies may be attributed to the different species or substrates under study, as well as the different analytical methods implemented (Yakushev et al., 2009; GómezBrandón et al., 2012; Koubová et al., 2015).

\section{The Endogeics}

Although endogeic earthworms have been less studied, results show contrasting effects on microbial abundance, compared with the epigeics (Figure 2). For endogeics, the majority of the works that observe their impact on the microbiome are made comparing soils with and without earthworms. There are less studies on the "hotspots" (gut and fresh casts). In mesocosms with soil from arable fields (3.8\% of organic matter) and potato residues on the surface, the endogeic Aporrectodea caliginosa did not impact soil microbial biomass which was obtained from the biovolume of bacterial numbers measured by confocal laser scanning microscopy (Postma-Blaauw et al., 2006). In contrast, Chang et al. (2016) found an increase in the bacterial biomass of a forest soil mixed with litter, measured through PLFA, in the presence of Octolasion lacteum. Similar findings were reported for a pot experiment by Braga et al. (2016), who detected increases in the bacterial 16S rRNA gene abundance in soils with the tropical earthworm Pontoscolex corethrurus, compared with soils without earthworms. In another study, microbial activity increased 6-fold in the gut of $P$. corethrurus and 1.6-fold in its casts, compared with the surrounding vertisol; more CFU were also observed in the casts by plate counting (Barois and Lavelle, 1986; Barois, 1987). Contrastingly, soil microbial biomass has also been shown to decrease with increasing endogeic earthworm biomass (Scheu et al., 2002). Chapuis-Lardy et al. (2010) found that fungal and bacterial biomass significantly decreased $(\sim 2$-fold) in casts from $P$. corethrurus when compared to the parent soil, although the fungal-to-bacterial ratio was not modified by the earthworm casting activity. The effect of endogeic earthworms on soil microbial biomass may also depend on the soil depth: it decreases with soil depth (Sheehan et al., 2008).

\section{The Anecics}

The anecic worms feed on the surface and build permanent tunnels that allow them to mix the different soil horizons. They form middens on the soil surface at the entrance of their burrows that contain visible pieces of organic matter and casts, these as well are excreted into the soil profile.

The impact of anecics on the soil may reach the whole soil profile and this is not the case with the other functional groups. Most reports show that anecic earthworms have a positive or neutral impact on microbial abundance in the soil (Figure 2), 

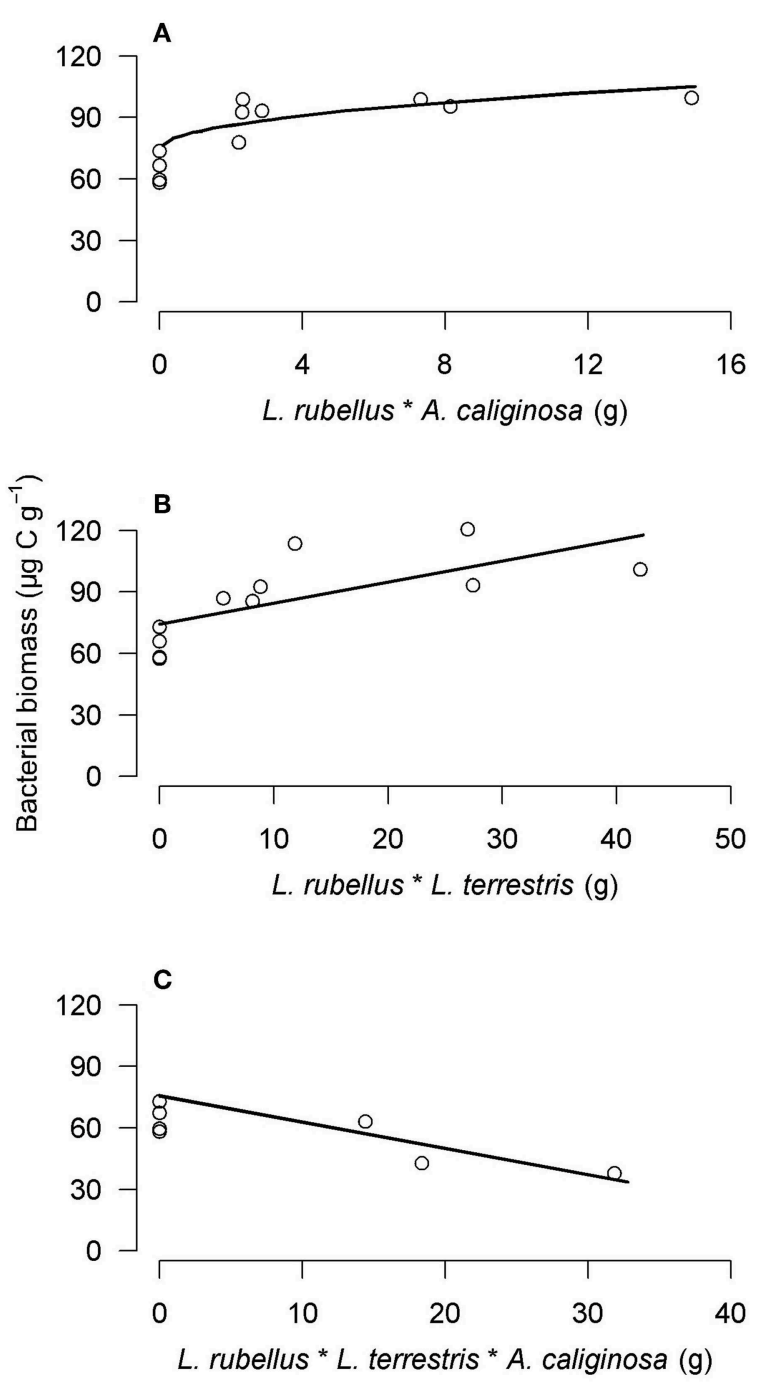

FIGURE 3 | Partial residual plots of the interaction effects (*) between (A) $L$. rubellus and $A$. caliginosa $(\mathrm{g}),(\mathbf{B}) L$. rubellus and $L$. terrestris $(\mathrm{g})$ and $(\mathbf{C}) L$. rubellus, $A$. caliginosa and $L$. terrestris ( $\mathrm{g}$ ) on the bacterial biomass $\left(\mu \mathrm{g} \mathrm{C} \mathrm{g}^{-1}\right)$, as determined by backward regression analysis (modified from Postma-Blaauw et al., 2006).

although this may be biased by the fact that most studies are carried out in temperate regions, using Lumbricus terrestris as a model species. As shown in Figure 2, very few reports are available for anecics in tropical regions.

Devliegher and Verstraete (1997) showed that the number of CFU in the soil surface layer $(0-5 \mathrm{~cm})$ was $60-320$ times larger in the casts of $L$. terrestris, fed with lettuce, than in the surrounding soil. In a deeper layer $(5-22 \mathrm{~cm})$, the magnitude of the increase was lower but still significant, with 6-32 times more bacterial CFU in the drilosphere than in the soil. The influence of soil depth was further corroborated by Sheehan et al. (2008), who observed a differential impact of the anecic worms Lumbricus friendi and Aporrectodea longa on microbial biomass depending on the soil horizon under study. In a microcosm experiment using soil and litter from lime (Tilia cordia), the anecic L. terrestris induced more microbial biomass in soil retrieved from its burrow walls, compared with the surrounding soil (Tiunov et al., 2001). However, these results seem to depend on the litter source and the soil Corg and $\mathrm{N}$ content, as the same experiment repeated with beech litter soil (which has three times more Corg and $\mathrm{N}$ than the lime litter soil) showed a smaller increase in burrow microbial biomass. Stromberger et al. (2012) also evidenced a larger abundance of microorganisms measured by PLFA in the burrow walls of $L$. terrestris when compared with the bulk soil (89.4 and $56.7 \mathrm{nmol} \mathrm{g}^{-1}$ soil respectively). Similar results measured also with microbial PLFA were found by Sampedro and Whalen (2007) in the gut of L terrestris and by Aira et al. (2009) in middens. Overall, most of the literature points towards a positive effect of anecics on microbial biomass in their burrows, middens, or casts, although a few reports observed a neutral effect (Postma-Blaauw et al., 2006) or negative effect (Zhang et al., 2000; Yu et al., 2008).

Although most studies focus on the effect of one earthworm species or species from the same ecological category on microbial biomass, it is important to remember that all three functional groups coexist in natural conditions. Investigating the earthworm impact on soil microorganisms should therefore integrate the whole earthworm community. Few studies have taken this point into account, with the exception of Postma-Blaauw et al. (2006) who showed that, although L. terrestris (anecic) did not have any effect on soil microorganisms, the combined presence of L. rubellus (epigeic) and L. terrestris induced an increase in microbial biomass. These authors also observed a smaller increase in the microbial biomass when L. rubellus and A. caliginosa (endogeic) were tested together, and a decrease of the microbial biomass when all three functional groups were combined (Figure 3). The importance of investigating the combined effect from distinct earthworm functional groups was further confirmed by Scheu et al. (2002) who determined, in a mesocosm experiment, that when epigeics (three species) and endogeics (three species) were put together, soil microbial biomass was larger than that observed when each earthworm group was studied independently. Finally, it must be considered that assessing soil microbial biomass as a whole may hide the spatial heterogeneity of the effect of earthworms. This could increase microbial abundance only in hot spots and decrease it in the bulk soil, with the resulting effect depending on the rate of soil ingestion, earthworm density, and presence of the functional groups (Sheehan et al., 2008). Considering microbial abundance as a whole can also prevent the detection of the fact that some specific microbial taxa may have been promoted while others hindered. Therefore, it is important to look at how earthworms modify microbial community structure.

\section{IMPACT OF EARTHWORMS ON THE STRUCTURE OF SOIL MICROBIAL COMMUNITIES}

By feeding on soil and influencing soil factors such as porosity, water content, mineral $\mathrm{N}\left(\mathrm{NO}_{3}^{-}, \mathrm{NH}_{4}^{+}\right)$or organic matter 
content, earthworms modify soil habitats and their resident microbial communities. In this section, we will make available information regarding the impact of earthworms on the structure and diversity of soil microbial communities and determine whether the resulting changes are consistent among functional groups of earthworms.

\section{Earthworms Modify the Diversity of Soil Microbial Communities}

The effect of earthworms on the richness and diversity of microbial communities can be neutral, negative or positive, depending on the earthworm species and on the "microhabitat" considered, i.e., whether the study focuses on the earthworm gut, casts, or on the surrounding soil. Neutral effects of earthworms on soil bacterial communities have been reported by de Menezes et al. (2018), who showed that the introduction of the endogeic Aporrectodea trapezoides did not influence the number of bacterial OTUs (Operational Taxonomical Units) nor the Chaol richness estimator of the whole soil. On the other hand, positive effects on bacterial richness and diversity were observed by Hoeffner et al. (2018) in the burrows created by four epi-anecic species from the Lumbricus genus, compared to the bulk soil. These authors, however, showed that fungal diversity remained unaffected by the earthworms. The impact that earthworms may have on soil microbial diversity was also investigated through the study of the vermicomposting process. The epigeic earthworms Eudrilus sp. or E. fetida increased bacterial diversity in the substrate, at least during the first stages of their vermicomposting (Vivas et al., 2009; Gopal et al., 2017), which showed the importance of considering different time scales in the study of bacterial diversity enhancement.

Contrary results were observed when considering earthworm gut and casts. Negative effects of earthworms on bacterial richness were found in earthworm gut and casts by Koubová et al. (2015), who showed that bacterial species richness (estimated from culturable bacteria) decreased during the passage through the epigeic Eisenia's gut. Soil ingestion by epigeic earthworms was also reported to decrease microbial diversity, as observed in the gut of Eudrilus sp. (Gopal et al., 2017) and in casts of L. rubellus (Furlong et al., 2002). This decrease in microbial diversity after soil ingestion has been attributed to the increased dominance of several bacterial groups in the earthworm casts, more specifically to an enrichment in bacterial taxa able to degrade benzoic and aromatic compounds (Furlong et al., 2002; Gopal et al., 2017). Further studies evidenced that the type of food that earthworms ingest seems to have little influence on the diversity of bacterial communities in casts, as shown by Aira et al. (2016) in the epigeic $E$ andrei.

Overall, these studies show that the influence of earthworms on microbial communities varies between micro-habitats, although Egert et al. (2004) only found slight differences between the community structure of bacteria and archea in the gut, the casts and the surrounding soil in the case of the anecic earthworm L. terrestris. On the other hand, for the same species, Sampedro and Whalen (2007) found that the microbiome of its gut was different from the bulk soil. The contrasting findings highlighted here may be partly explained by the different methods that were employed in the study of microbial diversity. Whilst several results were obtained by using Terminal Restriction Fragment Length Polymorphism (T-RFLP) (Egert et al., 2004; Hoeffner et al., 2018) or clone libraries of the bacterial 16S rRNA gene (Furlong et al., 2002), other studies have used next generation sequencing (NGS) to increase the resolution of diversity estimates (Gopal et al., 2017). The overall effect of earthworms on the soil microbial community also depends on soil conditions, particularly nutrient content. Koubová et al. (2015) showed that the effect of the epigeic earthworm E. fetida on soil microbial community biomass and composition, assessed through PLFA and culturable bacterial counts, was stronger in nutrient-poor habitats, where the stimulation of bacterial growth in the earthworm intestine was more noticeable.

\section{Earthworms Modify the Abundance of Specific Taxa Within the Microbial Community}

Soil passage through earthworm gut has been reported to consistently increase the abundance of specific bacterial groups within the microbial community, such as that of Flavobacterium (Schönholzer et al., 2002), Actinobacteria (Furlong et al., 2002; Rattray et al., 2010; Aira et al., 2016; Gopal et al., 2017; Ma et al., 2017), Firmicutes (Furlong et al., 2002; Rattray et al., 2010; Singh et al., 2015; Gopal et al., 2017; Ma et al., 2017) and $\gamma$-Proteobacteria, in particular members of the Pseudomonas genus; (Furlong et al., 2002; Aira et al., 2016; $\mathrm{Ma}$ et al., 2017). Earthworms generally promote the growth of fast-growing bacteria such as $\gamma$-Proteobacteria due to the labile carbon substrates they produce (Braga et al., 2016) in their gut or from their skin, which leads to increases in the Proteobacteria:Acidobacteria ratio (Gong et al., 2018). Specific functional groups have also been shown to be enhanced by the presence of earthworms, such as denitrifiers (Ihssen et al., 2003) or cellobiose utilizers (Karsten and Drake, 1995). Sampedro and Whalen (2007) also found significant changes in microbialderived PLFA profiles of soil and gut and described that gut passage significantly increased the concentration of biomarkers indicative of aerobic bacteria, microeukaryotes, and fungi.

The advent of high-throughput sequencing of 16S rRNA gene amplicons has allowed us to confirm and refine these results. The presence of endogeic earthworms (A. trapezoides, Metaphire guillelmi, or $P$. corethrurus) is associated with increases in Bacteroidetes (especially in Flavobacteriaceae and Sphingobacteriales), $\beta$-Proteobacteria (especially in Rhodocyclaceae), Firmicutes (especially in Paenibacillaceae), Verrucomicrobia and ammonia-oxidizing Nitrosovibrio in the soil (Bernard et al., 2012; de Menezes et al., 2018; Gong et al., 2018). The observed enrichment in these bacterial taxa is usually attributed to an increase in the mineralisation of organic residues (Bernard et al., 2012). Bernard et al. (2012) and de Menezes et al. (2018) also found a promotion of chitinolytic bacterial taxa by $P$. corethrurus and A. trapezoides, respectively, such as Chitinophagaceae, Cytophagaceae, Neisseriaceae, and Microbacteriaceae. The release of chitin in the soil, either 
through the production of chitinase by earthworms or through the degradation of fungal hyphae during gut passage, may be responsible for this increase in chitinolytic bacteria. In general, gut bacteria of anecic and endogeic earthworms seemed to be determined, in descending order of importance, by earthworm ecological group, habitat, and species (Thakuria et al., 2010).

In the epigeic earthworms E. fetida and Perionyx excavatus, gut bacterial communities were shown to be dominated by Proteobacteria, Actinobacteria, and Firmicutes, with several differences according to the species. Verrucomicrobia and Chloroflexi were abundant in the gut of E. fetida whilst they were absent in that of $P$. excavatus. On the contrary, Spirochaetes were abundant in P. excavatus but not in E. fetida (Singh et al., 2015). The earthworm intestinal tract constitutes an environment that is enriched in $\mathrm{C}, \mathrm{N}$ and water content and impoverished in oxygen when compared with the surrounding soil (Barois and Lavelle, 1986). It has therefore been consistently shown to favour the occurrence of anaerobic or facultatively anaerobic bacteria and archea (Barois et al., 1987; Horn et al., 2003; Koubová et al., 2015). Bacterial genera such as Aeromonas, Bacillus, Clostridium, Paenibacillus, Propionibacterium, or Staphylococcus were shown to be abundant in the guts of epigeic Eisenia earthworms (Toyota and Kimura, 2000; Shin et al., 2004; Koubová et al., 2015). König (2006) reported that Bacillus and Paenibacillus, in particular, were commonly detected in the gut of earthworms and were especially relevant since they were able to degrade aromatic compounds under oxygen limiting conditions.

Although consistent patterns could be observed, the effect of earthworms on soil bacterial community composition seems to be mostly dependent upon the type of substrate under study (de Menezes et al., 2018). This was demonstrated by Gopal et al. (2017) who showed that bacterial community structure changed throughout the vermicomposting process, as nutrient dynamics were modified. Gong et al. (2018) reported a decrease in the relative abundance of Cloroflexi and Fibrobacteres by the anecic M. guillelmi in rice fields where mulch was applied, whereas their dominance increased in rice fields where straw was incorporated. These authors also reported a shift in keystone taxa within the soil microbial community, which was dependent upon the applied organic amendment. These findings were consistent with those described by Koubová et al. (2015), who recorded distinct shifts in microbial taxa depending on the environment under study. Earthworm (Eisenia spp.) excreta were enriched in Actinobacteria in compost pile (plant remains) whereas they were enriched in Firmicutes in large scale vermiculture plant (cattle manure and agricultural waste) and forest soil. On the other hand, increases in Gammaproteobacteria were detected in the gut of earthworms. Increases in Gammaproteobacteria were also found by Fjøsne et al. (2018) in the soil when the epigeic earthworm Dendrobaena veneta was present. These authors consistently observed increases in Kluyvera cryocrescens and Pseudomonas putida, independently from the initial composition of the soil microbial community.

To synthesize the available information, we looked at how often microbial phyla were found in soils or substrates influenced by earthworms belonging to different ecological groups. Figure 4 shows that Proteobacteria, Actinobacteria, Firmicutes,
Acidobacteria, Planctomycetes, Bacteroidetes, Nitrospirae, and Chloroflexi have the highest relative abundance in soils where earthworms are present, regardless of the ecological category they belong to. Although epigeic earthworms seem to induce a higher microbial diversity than endogeic and anecic earthworms, these latter may impact the soil bacterial community in a more consistent manner, as shown by a lesser proportion of rare phyla (Figure 4). A network analysis (Figure 5) confirmed that the above referred eight phyla form the core of the network while interacting or being promoted by most earthworm species. It also revealed that epigeic earthworms promote more rare phyla of bacteria (seven phyla) than do endogeic earthworms (two phyla). Altogether, these findings suggest that some bacterial taxa respond in a consistent manner to the presence of earthworms and could constitute good indicators for predicting the impact of earthworms on soil ecosystems.

\section{THE IMPACT OF EARTHWORMS ON NUTRIENT CYCLING THROUGH THE MODIFICATION OF SOIL MICROBIAL COMMUNITIES}

Earthworms are decomposers feeding on organic matter, thereby releasing nutrients through digestion and excretion with direct consequences on plant growth (Figure 1, arrow 1). They also have an important impact on microbial communities which in turn affects nutrient cycling and plant development through their interactions (Figure 1, arrows $2 \mathrm{a}$ and $2 \mathrm{~b}$ ). In a recent study, Braga et al. (2016) showed that the introduction of the endogeic $P$. corethrurus in the soil significantly changed around 70 microbial functions in the bulk soil and in the rhizosphere, which were mainly related to biosynthesis and plant-microbe symbiosis. The presence of earthworms also modified the ecological interactions among microbial functions. As shown in the previous section, earthworms stimulate certain microbial taxa, and by doing so increase the importance of keystone functions (Braga et al., 2016). In this section, we will summarise the main findings concerning the impact of earthworms on microbial functions, emphasising how information about earthwormassociated microbial communities needs to be integrated in order to improve knowledge of the influence of earthworms on nutrient cycling.

\section{Earthworms Increase Nutrient Mineralisation in the Soil}

Earthworms, in particular endogeic geophagous earthworms, are known to promote $\mathrm{C}$ and $\mathrm{N}$ mineralisation in the soil (Lavelle et al., 1998; Araujo et al., 2004; Coq et al., 2007; Gopal et al., 2017), most likely through a priming effect affecting decomposition rates of the soil organic matter (SOM) (Barois et al., 1987; Bernard et al., 2012). This positive priming effect is expected to promote the recycling of nutrients, especially of organic N and P, in the SOM (Kuzyakov et al., 2000; Bertrand et al., 2015). This has been shown for P. corethrurus in several studies, summarised in the recent review by Taheri et al. (2018). 


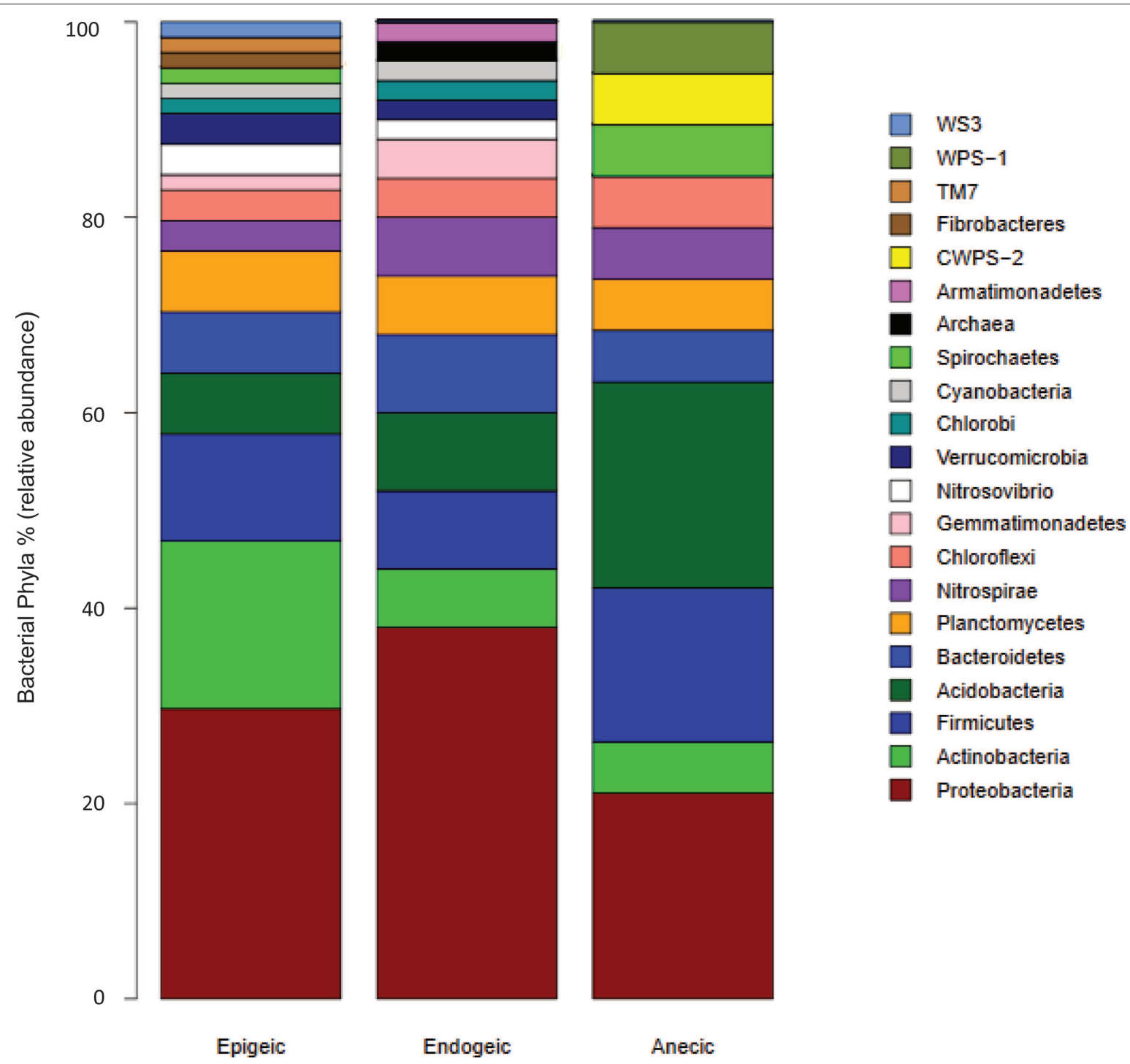

FIGURE 4 | Relative abundance of microbial phyla reported in soils or substrates processed by earthworms of different functional groups. Data was obtained from 11 peer-reviewed publications retrieved after a search made using the words: "earthworms," "soil microbial communities," and "phyla" in the Web of Science from 2009 to 2018 (before that, no information was found with the keywords "microbial phyla").

Two to three-fold increases in mineralised $\mathrm{C}$ have also been observed in casts of the endogeic A. caliginosa, compared with the surrounding soil, which is attributed to the priming effect caused by earthworm ingestion and digestion (Abail et al., 2017). Epigeic earthworms such as E. fetida and P. excavatus have also been reported to enhance the decomposition rates of organic matter (Singh et al., 2015).

The increase in SOM mineralisation in earthworm casts, compared with the surrounding soil, is associated with an enrichment in labile compounds and with a subsequent increase in microbial activity (Barois and Lavelle, 1986; Coq et al., 2007; Abail et al., 2017), which could be attributed to the earthworm digestion itself and to the influence of the gut microbiome. The enhancement of r-strategist bacteria with fast growth rates and specialised catabolic capabilities (Bernard et al., 2012), which are thought to be responsible for the observed increase in SOM mineralisation by earthworms, was defined by Lavelle et al. (1995) as the "Sleeping Beauty" paradox. As described previously, the promotion of fast-growing bacteria $(\gamma$ Proteobacteria for example) may be driven by the $\mathrm{N}$-rich gut mucus, changes in soil physico-chemical characteristics or to the degradation of fungal biomass during gut transit, through which earthworms can produce labile C substrates (Brown, 1995; Brown et al., 2000; Braga et al., 2016). The induction of a priming effect by earthworm gut transit is further confirmed by observations showing that SOM mineralisation rates are lower in old casts than in recent ones (Pulleman et al., 2005; Bertrand et al., 2015). 


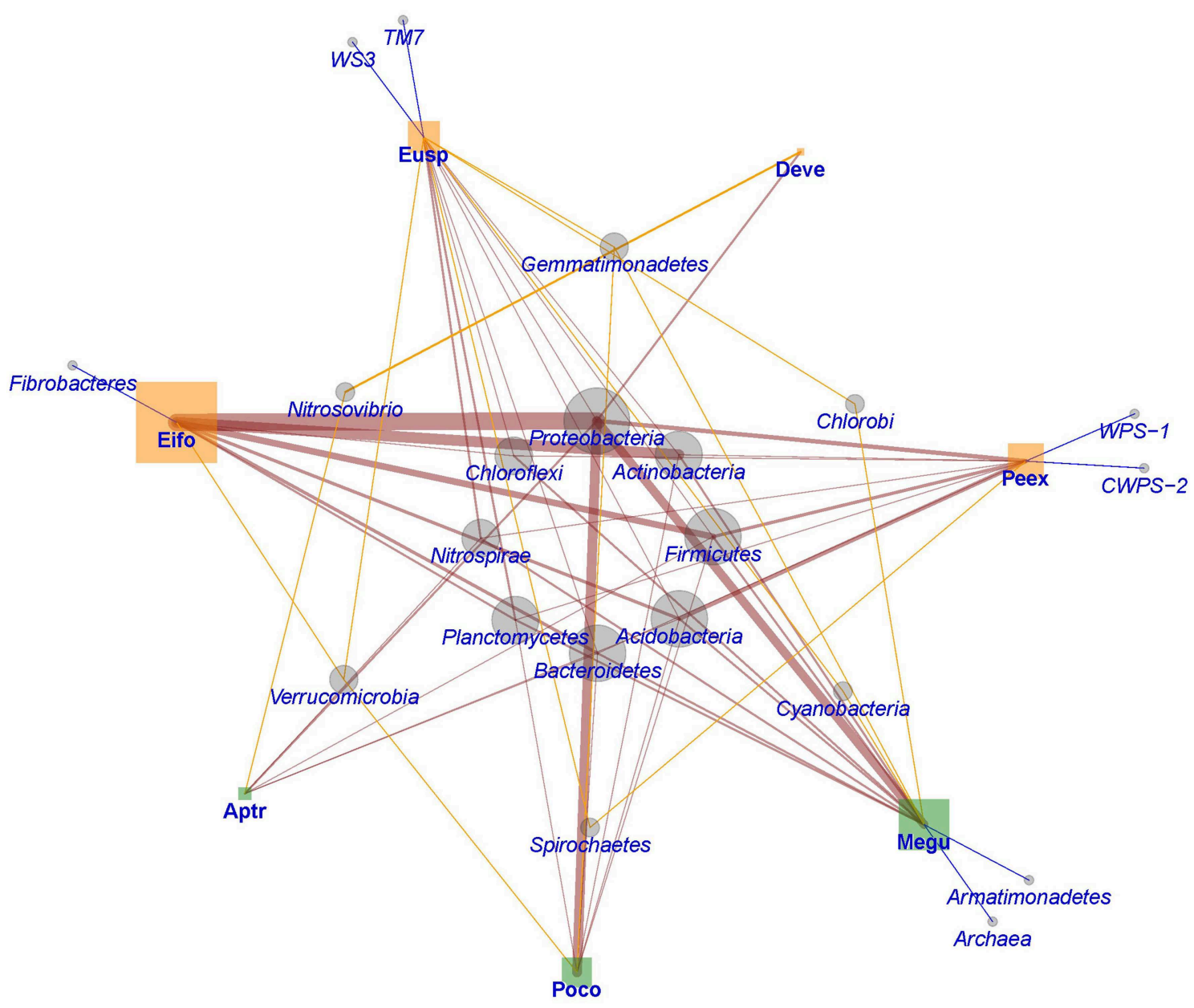

FIGURE 5 | Network representation of microbial phyla (circles) in soils or substrates processed by earthworms (squares) of different functional groups (green = endogeic and orange = epigeic). The size of the figures represents the relative frequency of reports for each taxon whilst the width of the links is the relative frequency of each pair of interactions $(n=11)$. Aptr, Aporrectodea trapezoides; Deve, Dendrobaena veneta; Eifo, Eisenia fetida; Eusp, Eudrilus sp.; Megu, Metaphire guillelmi; Peex, Perionyx excavatus; Poco, Pontoscolex corethrurus. The data is the same as that used in Figure 4.

Although the effect of earthworms on soil $\mathrm{N}$ dynamics may vary depending upon the species considered (Clause et al., 2014; Groffman et al., 2015), increases in mineral $\mathrm{N}$ in earthworm casts from the different functional groups have been consistently observed (Decaëns et al., 1999; Aira et al., 2005; Clause et al., 2014). Mineral N concentrations have been measured as 5folds in casts of $P$. corethrurus when compared with those of the surrounding soil (Lavelle et al., 1992). Increases of 31 and $4 \%$ in soil $\mathrm{NO}_{3}^{-}-\mathrm{N}$ and $\mathrm{NH}_{4}^{+}-\mathrm{N}$, respectively, have also been observed in soils with the presence of $A$. caliginosa (McDaniel et al., 2013). The epigeic E. fetida also enhanced organic $\mathrm{N}$ mineralisation in the rhizosphere of Phormium tenax, a New Zealand lilaceous perennial (Zhong et al., 2017). The overall positive effect of earthworms on $\mathrm{C}$ and $\mathrm{N}$ mineralisation in the rhizosphere was shown by $\mathrm{Wu}$ et al. (2017) who demonstrated that $P$. corethrurus affected $\mathrm{C}$ and $\mathrm{N}$ processes and the soil microbial community in plots where living plants were present, in contrast to plots where artificial plants were used as controls.
This was further confirmed by Athmann et al. (2017) who evidenced a positive effect of root and earthworm (L. terrestris) biopores, compared with the bulk soil, on the activity of several enzymes involved in the $\mathrm{C}$ and $\mathrm{N}$ cycle, resulting in an increase in nutrient mobilisation. These findings point out a positive interaction effect on nutrient mineralisation at the drilosphere and rhizosphere level, two hotspots of microbial activity in the soil. As recently highlighted by Bray et al. (2019), there is a stimulatory effect of earthworms and other soil macrofauna on rhizosphere microbial communities and on the microbially-mediated processes, particularly on $\mathrm{N}$ mineralisation and SOM formation.

The enhancement of $\mathrm{C}$ and $\mathrm{N}$ mineralisation by the earthworm-associated microbiota is mediated by an increasing enzyme activity. Some of the bacterial taxa that may be promoted by earthworms, such as Pseudomonas spp., have been associated with the production of enzymes involved in the degradation of complex organic molecules, which could favour 


\section{BOX 1 | Earthworms interact with mycorrhizal fungi}

Beside soil bacteria, fungi are key organisms in the dynamics of soil biogeochemistry and its ultimate effect on plant growth. In contrast to with bacteria, much less information is available regarding their interactions with earthworms and the outcome of these interactions. Most of the attention, if not all in the fungi-earthworm interactions have been focused on arbuscular mycorrhizal fungi. In a similar way to the interaction with bacteria, the interactions between earthworms and mycorrhizal fungi, particularly arbuscular mycorrhizal fungi, have been found to modify the soil chemistry (Zhang et al., 2016, 2018) and soil nutrient availability (Milleret et al., 2009; Xiang and Li, 2014) and, critically important, the uptake of nutrients by plants (Milleret et al., 2009; Li et al., 2012, 2013a,b; Aghababaei et al., 2014) and the composition and abundance of the fungal community (Gormsen et al., 2004; Dempsey et al., 2013; Cao et al., 2015a,b,c, 2016, 2018; Zhang et al., 2016). Although the understanding of the interactions between earthworms and mycorrhizal fungi has not been the primary focus of most published works, there is a considerable amount of data that permits us to gain some insights on these interactions and their synergistic effects on plant performance (Wurst et al., 2004; Yu et al., 2005; Zaller et al., 2011; Li et al., 2013b).

The scientific interest in the interactions between earthworms and mycorrhizal fungi dates back almost 30 years and tackled the fundamental question of how the trophic activity of earthworms affects the availability of infective units of mycorrhizal fungi. While all studies focused on the abundance of spores of mycorrhizal fungi in earthworms' casts found a concentration effect, the density of spores in the casts was on average 66\% higher than in surrounding non-earthworm processed soil (Gange, 1993; Harinikumar and Bagyaraj, 1994; Lee et al., 1996) and remained viable for up to a year (Reddell and Spain, 1991). Another investigation found no effect of earthworms in dispersing effectively the infective units of mycorrhizal fungi (Pattinson et al., 1997). However, it must be noted that the only investigation on the dispersion of mycorrhizal infective units by earthworms used a different species of earthworm (the endogeic $A$. trapezoides) compared to the many studies where concentration of the spores in the casts from different species were measured (the anecic $L$. terrestris and the endogeic $P$. corethrurus, Ochochaetona phillotti, and Lampito mauritii). As considerable variation has been reported among species of earthworms in their ability to concentrate infective units of mycorrhizal fungi, the lack of support for the capacity of earthworms to disperse the infective units of mycorrhizal fungi must be taken with caution until further investigation including the three functional groups of earthworms (anecic, endogeic, and epigeic) is carried out.

Over $60 \%$ of the reviewed cases reported that earthworm activities enhanced root colonization by mycorrhizal fungi while $25 \%$ reported a reduction in root colonization. It is worth noting that while for anecic and epigeic earthworms the ratio of positive to negative and neutral effects on root colonization by mycorrhizal fungi worked out to $3: 1$ and 4:1, respectively, for endogeic species this was inverted to a 1:2 ratio. The mechanisms that may differentially affect root colonization by mycorrhizal fungi when interacting with anecic/epigeic, and endogeic earthworms are poorly understood. Drilling by earthworms may damage the hyphal networks and fine roots of plants (Gange and Brown, 2002; McLean et al., 2006). Horizontal drilling of endogeic species may cause a more extensive disruption of the extraradical mycelium compared to the vertical burrowing of anecic species and this may affect the capacity of the fungi to colonize the roots. Cast deposits on the surface of the soil carried out by epigeic and anecic species may favour the dispersion of mycorrhizal infective units and this in turn may favour the colonization of roots. The unique investigation tackling the question of earthworms as dispersion agents of mycorrhizal infective units showed negative results and concordantly was carried out with endogeic species, which are frequently reported to decrease root colonization by mycorrhizal fungi. A likely explanation is that fungi are often considered as earthworm food (Curry and Schmidt, 2007; Shan et al., 2013). No data exists regarding the effectiveness of anecic and epigeic species in dispersing infective propagules of mycorrhizal fungi. Therefore, a comparative study of earthworms with different ecologies as dispersing agents of mycorrhizal infective units is needed. Additionally, earthworms may favour root colonization by mycorrhizal fungi indirectly by promoting particular groups of soil microorganisms that may cooperate with mycorrhizal fungi (Zhang et al., 2016). Whether earthworms of different behaviours could favour the proliferation of particular microbial groups that in turn facilitate the interaction between mycorrhizal fungi and plant roots is a totally unexplored area, although some efforts report correlative changes of Gram positive bacteria together with mycorrhizal fungi (Dempsey et al., 2013).

A major drawback in the investigation of the interaction between earthworms and mycorrhizal fungi is that only a handful of species of fungi have been used in the experimentation (Rhizophagus intraradices, Rhizophagus irregularis, Funneliformis mosseae, Glomus geosporum, Glomus caledoniun, Glomus etunicatum, Claroideoglomus claroideum, and Acaulospora sp.), all from the Glomeraceae. This means that our understanding of these interactions is rather partial and efforts need to be made to understand the dynamics of these interactions with a wider range of species of fungi from different families as it is known that there are marked differences in colonization rates, growth of extra-radical mycelium and capabilities to move soil nutrients to their host plants. Surprisingly, we are aware of no study documenting the role of earthworms as potential drivers of the composition and structure of mycorrhizal communities. Simple pot and mesocosm experiments with known initial composition of added mycorrhizal communities with and without earthworms will help to advance this field. This is important as a great deal of efforts are being made to include earthworms and mycorrhizal fungi in sustainable agricultural practices and we need to understand their fundamental interactions and outcomes.

SOM decomposition (Bertrand et al., 2015; Fjøsne et al., 2018). Enzymes produced by the earthworm-associated microbiota are also responsible for the reported increases in soil $\mathrm{NO}_{3}^{-}-\mathrm{N}$ and $\mathrm{NH}_{4}^{+}-\mathrm{N}$ in the presence of earthworms. For example, the activity of the soil enzyme $\beta$-N-acetylglucosaminidase has been shown to be promoted in presence of $P$. corethrurus, which resulted in " $\mathrm{NH}_{4}^{+}-\mathrm{N}$ hotspots" that might be accessed by arbuscular mycorrhizal fungi (Box 1), hence providing benefits for plant growth ( $\mathrm{He}$ et al., 2018). Increases in phenol oxidase and glucosidase activity by earthworms and other macrovertebrates were also observed in the rhizosphere of Festuca arundinacea (Bray et al., 2019), and were attributed to the ingestion of fine roots and the stimulation of microbial activity during gut passage.

The reduction of microbial immobilisation has been suggested as another driver of enhanced $\mathrm{N}$ mineralisation by earthworms, which may ultimately lead to an increase in $\mathrm{NO}_{3}^{-}-\mathrm{N}$ leaching
(Domínguez et al., 2004). Some authors, however, did not detect any earthworm effect on potentially mineralisable $\mathrm{N}$ (Fonte and Six, 2010) or, on the contrary, evidenced a decrease in $\mathrm{N}$ mineralisation by earthworms (Groffman et al., 2015), most likely due to an increase in microbial immobilisation that caused total soil $\mathrm{N}$ to decrease by $90 \mathrm{~g} \mathrm{~N} \mathrm{~m}^{-2}$ in presence of the epigeic L. rubellus. A possible explanation which has been proposed by several authors is that $\mathrm{N}$ mineralised by earthworms and their associated microorganisms might be used more readily by plants, thereby masking an increase in soil available $\mathrm{N}$ concentrations (Pashanasi et al., 1996; González and Zou, 1999; Wu et al., 2017).

Similarly, the amount of readily available phosphorus (P) has been shown to be affected by earthworms, levels of available $\mathrm{P}$ being higher in casts (Jiménez et al., 2003; Kuczak et al., 2006; Vos et al., 2014; Ros et al., 2017) or in biopores formed by L. terrestris (Athmann et al., 2017) than in the bulk soil. 

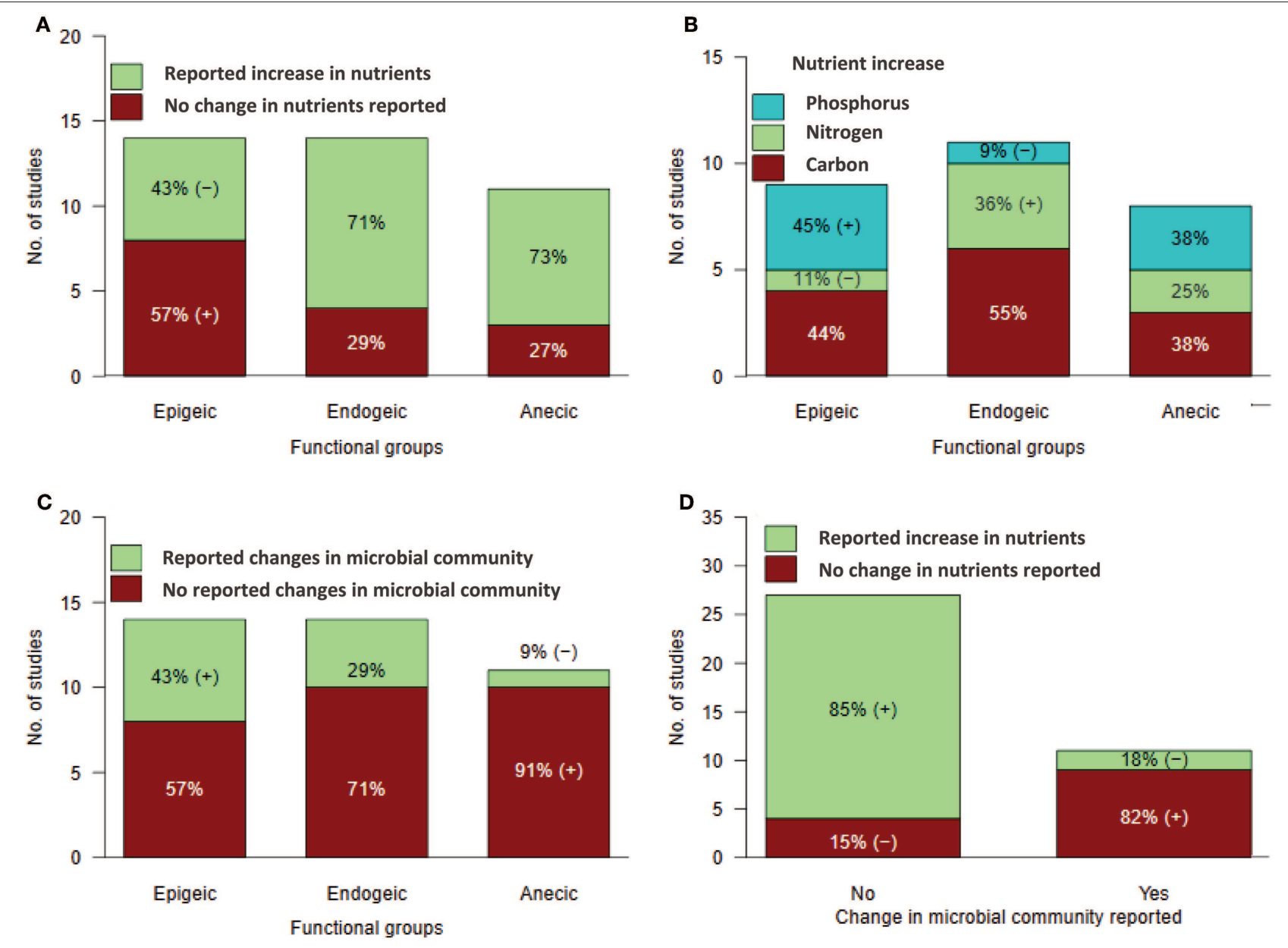

FIGURE 6 | Frequency of studies reporting: (A) overall changes in soil nutrients when processed by earthworms of different functional groups, (B) increments in carbon, nitrogen and phosphorus in the soil or substrates when processed by earthworms of different functional groups, (C) overall changes in the soil microbial community when the soil was processed by earthworms of different functional groups and (D) concurrence of data revealing changes in the soil microbial community and in the soil nutrients. Percentage values are relative to each bar. $(+)$ and $(-)$ indicate when the frequency of studies is higher or lower respectively than that expected under the null hypothesis: the chances of detecting nutrient increments are independent of the functional group of the earthworms. Data was obtained from 40 peer-reviewed publications retrieved after a search made using the words: "earthworms," "soil microbial communities," "nitrogen," "phosphorus," and "nutrient cycling" in the Web of Science from 2003 to 2018. In Figure 6B only 70\% of the studies were taken into account as only increases in nutrients were considered.

Concentrations of water-extractable $\mathrm{P}$ in casts of the anecic earthworm L. terrestris have been reported to be 30-1000 times larger than those found in bulk soil (Ros et al., 2017). These earthworm-induced "P hotspots" depend upon the earthworm species and have been shown to be larger for the epigeic $L$. rubellus than for the anecic $L$. terrestris or the endogeic $A$. caliginosa (Vos et al., 2014). The influence of earthworms on available $\mathrm{P}$ is particularly relevant in the rhizosphere, where earthworms can interact with arbuscular mycorrhizal fungi to enhance P solubility and transfer to the plant (Milleret et al., 2009; Cao et al., 2015a) (Box 1). Soil available P has been reported to increase in the presence of the endogeic earthworm $P$. corethrurus (Lopez-Hernandez et al., 1993; Chapuis-Lardy et al., 1998; Patron et al., 1999), or of epigeic E. fetida (Cao et al., 2015a), which has been linked to the enhanced microbial activity during soil ingestion or in earthworm casts, although the magnitude of the increase in available $\mathrm{P}$ may differ depending on earthworm functional groups (Wan and Wong, 2004; Bernard et al., 2012; Vos et al., 2014).

Our synthesis of literature over the past 15 years revealed that endogeic and anecic earthworms induced an increase in soil nutrients in around $70 \%$ of the consulted studies; epigeic earthworms, however, only induced an increase in soil nutrients in $43 \%$ of the reported studies (Figure 6A). When analysing the effects of the different earthworm functional groups on particular nutrients $(\mathrm{C}, \mathrm{N}$, and $\mathrm{P})$, more differences emerged. Epigeic earthworms were reported to increase $\mathrm{P}$ levels in the soil or substrate under study more frequently than expected under the null hypothesis, whilst endogeics were associated with $\mathrm{N}$ increases in the soil more frequently 
than the other two groups of earthworms (Figure 6B). It is noteworthy that the reported increases in soil nutrients by earthworms were rarely related to changes in the soil microbial community (Figures 6C,D); moreover, when changes in microbial communities induced by earthworms were investigated, most studies (82\%) did not report associated changes in soil nutrient contents (Figure 6D). Considering the functional groups of the bacterial phyla promoted by earthworms (mainly Proteobacteria, Actinobacteria, Firmicutes, and Acidobacteria) it is expected that the observed changes in nutrient availability associated to earthworms are at least in part caused by the metabolic activity of bacteria rather than by direct effects of the earthworms. This calls for more studies integrating earthworm effects on soil microbial communities at a taxonomic and functional level, to unravel the link between microbial diversity and ecosystem functions.

\section{Earthworms Affect Microbial Functional Genes Involved in Nutrient Cycling}

The influence of earthworms on nutrient cycling is not restricted to their impact on SOM mineralisation through an induced priming effect. Several studies have also demonstrated a direct effect on the expression of bacterial genes involved in the $\mathrm{N}$ cycle. Soil $\mathrm{N}$ transformations, and thus soil fertility, have often been investigated through the study of microbial functional genes, which emphasise their importance as functional genetic markers (Hosseini Bai et al., 2015; Ribbons et al., 2018).

Generally, the presence of earthworms has been associated with an increase in denitrification. The presence of the endogeic $P$. corethrurus was shown to increase the abundance of bacterial functional genes related to denitrification (nirK and nos $Z$ ) in the soil and in the rhizosphere (Chapuis-Lardy et al., 2010; Braga et al., 2016). Similar findings were found by Nebert et al. (2011) for the epigeic L. rubellus. The expression of the nos $Z$ gene, which encodes for the nitrous oxide $\left(\mathrm{N}_{2} \mathrm{O}\right)$ reductase, is directly linked with the amount of $\mathrm{N}_{2} \mathrm{O}$, an important greenhouse gas (GHG) of which earthworms are thought to be promotors (de Menezes et al., 2018). An increase in the abundance of the nos $Z$ gene in the presence of earthworms may indicate the presence of larger denitrifying bacterial communities (Reverchon et al., 2015), which are known to be influenced by the quantity and composition of organic compounds resulting from the decomposition of organic residues (Kandeler et al., 2006). Earthworms and their associated microbiota, by promoting the decomposition of SOM, could therefore create soil conditions that are able to sustain more abundant denitrifier communities. Horn et al. $(2003,2006)$ indicated that the earthworm gut is a microenvironment ideal for $\mathrm{N}_{2} \mathrm{O}$-producing bacteria and that gut denitrifiers are probably soil-derived. However, increases in $\mathrm{N}_{2} \mathrm{O}$ emissions and in the abundance of the gene nos $Z$ seem to be species-dependent, as no effect of the endogeic A. caliginosa was detected on denitrification genes (Nebert et al., 2011). This is also consistent with results by Depkat-Jakob et al. (2010) who found that nos $Z$-containing taxa were not uniformly stimulated in the guts of worms from different feeding guilds. On the other hand, the anecic earthworm Maoridrilus transalpinus was shown to reduce $\mathrm{N}_{2} \mathrm{O}$ emissions when associated with rhizobial bacteria, most likely due to the aerobic conditions created by burrowing, which are detrimental to denitrification (Kim et al., 2017). These contrasting findings may be due to the different experimental settings that were implemented to study the effect of earthworms on $\mathrm{N}_{2} \mathrm{O}$ emissions. Lubbers et al. (2013) for example, conducted a meta-analysis showing that earthworms increase GHG emissions, in which most referenced studies are based on very short and simplified experimental set ups, in which there are no plants to uptake the mineralised $\mathrm{N}$, which could indeed favour the emission of $\mathrm{N}_{2} \mathrm{O}$. Complexification of experimental set ups towards an integration of complex interactions between plants, macrofauna and microorganisms is therefore required in order to elucidate whether the presence of earthworms increase or decrease GHG emission in the long term.

Other microbial processes have also been reported to be positively affected by earthworms. Functional genes associated with carbohydrate and lipid metabolisms, biosynthetical pathways, translation, reduction-oxidation and cell proliferation processes were more abundant in the soil when $P$. corethrurus was present (Braga et al., 2016). The introduction of $P$. corethrurus also promoted microbial functions associated with plant-microbe symbiosis in the rhizosphere of sugarcane, such as plant cell colonization by $\mathrm{N}$-fixing bacteria or plant growth regulation (Braga et al., 2016). Finally, despite the reported effect of earthworms on $\mathrm{P}$ mobilisation, no studies have yet investigated, to the best of our knowledge, how earthworms may alter microbial functional genes associated with the $\mathrm{P}$ cycle.

\section{THE IMPACT OF EARTHWORMS ON SIGNAL MOLECULES PROMOTING PLANT GROWTH}

The positive effects of earthworms on plant growth and yield are known to be related to improved soil physico-chemical variables, as earthworms facilitate the penetration of roots in the soil, the absorption of nutrients and the exchange of gases (Figure 1, arrow 1). Recently, these positive effects have also been attributed to the soil microbiota (Figure 1, arrows 2a and $2 \mathrm{~b}$ ), through the activation of microorganisms producing signal molecules.

Despite all the literature documenting the co-occurrence between changes in the $\mathrm{N}$ cycle by earthworms and their positive effect on plant growth (Van Groenigen et al., 2014), some studies suggest that an increased nutrient mineralisation is not sufficient to explain the effect of earthworms on plant growth by itself (Blouin et al., 2006; Laossi et al., 2010). There are other concomitant mechanisms, especially the emission of signal molecules (SM) in the presence of earthworms, which are involved in the effect of earthworms on plant growth (PugaFreitas et al., 2012b) and help explaining the earthworms positive effects. SM are molecules with strong effects on plant physiology despite their presence at low concentration and are generally associated with qualitative changes. For example, SM are the main factors driving plant development and immunity (Taiz and Zeiger, 2010). In turn, these qualitative changes can induce 
quantitative changes (e.g., growth). It is important to notice, that SM differ from nutrients which are constitutive of biomass, generally present at relatively high concentration and mainly responsible for quantitative changes.

It is widely accepted that SM are not exclusively produced by plants. They are also produced by almost all soil organisms, including soil fauna and microorganisms (Brito-Vega and Espinosa-Victoria, 2009; Puga-Freitas and Blouin, 2015). Multiple organic compounds are included in SM, such as sugars, organic acids and vitamins; these compounds are often involved in the initiation of signalling pathways leading to the production of phytohormones (auxins, gibberellins, cytokinins, ethylene, and abscisic acid), as well as secondary metabolites or volatile compounds that activate the plant's immune system or regulate its growth and development. Up to date, it is unclear if soil fauna is able to produce these SM by itself, or if it activates microorganisms that produce them. However, Puga-Freitas et al. (2012a) revealed that culturable microorganisms extracted from earthworm-worked soils where producing more indole acetic acid (IAA) $(+46 \%)$ as compared with a control soil without earthworms, which supports the second hypothesis of a stimulation of bacteria (probably Plant Growth Promoting Bacteria, or PGPB) by earthworms.

Humic acids, IAA, aminocyclopropane-1-carboxylate (ACC), as well as molecules tentatively identified as auxins and ethylene have been reported as SM produced in the presence of earthworms, using indirect methods such as colourimetry. In many cases, their presence has been deduced from observations on plants that are similar to results observed in the presence of exogenous SM application. However, recent evidence shows that SM have been unequivocally identified by a reverse phase ultra-high-resolution liquid chromatography (UPLC) system coupled to a triple quadrupole mass spectrometry analyser, which allowed to determine the presence of jasmonic (JA), salicylic (SA), and abscisic acid (ABA) in vermicompost of E. fetida (Hernández, 2019). Nevertheless, the involvement of microorganisms in the secretion of these molecules was not elucidated with the exception of Pathma and Sakthivel (2013) who identified bacteria from E. fetida casts. Most of the studies investigating the chemical composition of SM in earthworm casts were conducted on epigeic earthworms, particularly on E. fetida, while one single paper studied the endogeic species Aporrectodea caliginosa (synonym Nicodrilus caliginosus) and Aporrectodea rosea (synonym Allolobophora rosea). Finally, all studies have solely been related to the casts of earthworms (Table 1). So far, there are no publications that confirm the isolation and unequivocal quantification of compounds such as auxins or gibberellins and the identity of the microorganisms associated with these molecules. Only two studies, at a 17-year interval (Canellas et al., 2002 and Hernández, 2019), provided an unambiguous identification of SM (humic acids with ABA, SA, and JA).

In the light of the new era of technology for the analysis and quantification of organic molecules, a new panorama opens to understand "the universe of molecules' diversity" of soil. More research is required to elucidate the most efficient extraction methods and identification of these molecules on earthworms or their casts. Transcriptomic approaches could also help unravel the microbially-mediated impact of earthworms on plant growth (Puga-Freitas et al., 2012b). Furthermore, considering the growing information available regarding earthworm-associated microbial communities, it is necessary to carry out more systematic research on the SM produced by microorganisms that are detected in earthworm digestive tracts, casts, and tunnels. Pseudomonas spp., for example, have been detected in the gut of E. fetida (Pathma and Sakthivel, 2013). Since Pseudomonas spp. have frequently been shown to emit SM that may promote plant growth, for instance through an induction of plant resistance to pathogens (Bloemberg and Lugtenberg, 2001; Pieterse et al., 2009; González et al., 2017); the combining next-generation sequencing with state of the art metabolomic tools may help understanding the joint effect of earthworm and PGPB on plant growth.

Regarding plant response to SM in the presence of earthworms, many observations of the "hormone-like effect" have been made with reference to vermicompost, for example increased growth and yield, development of flowers and fruits, and other processes related to tolerance to biotic and abiotic stresses (Table 1). In general, E. fetida, A. caliginosa and A. rosea are the earthworm species that have presented greater positive effects in plants, which has been attributed to the presence of IAA, ACC, and humic acids produced by their associated bacteria. Humic acids are SM extracted from vermicompost produced from cattle manure that also enhanced root growth and the number of sites of lateral root emergence in maize seedlings (Zea mays); these molecules were also shown to be responsible for a stimulation of the plasma membrane $\mathrm{H}+-$ ATPase activity (Canellas et al., 2002). Quaggiotti et al. (2004) reported an accumulation of $\mathrm{H}+$-ATPase gene transcripts in the roots and an increase of nitrate transporter gene transcripts in the shoots of plants exposed to earthworm-producing humic substances. Using a transcriptomic approach for the screening of gene expression in Arabidopsis thaliana, Puga-Freitas et al. (2012b) found an accumulation of transcripts of 57 genes, most of which are known to be induced by exogenous hormone application or microbial elicitors. They also showed the reversion of the dwarf phenotype of an A. thaliana mutant for IAA transport in the presence of earthworms, suggesting that earthworms were compensating the low auxin level in root cells by producing auxin-like compounds in the soil, which were able to penetrate plant roots (Puga-Freitas et al., 2012b). Transcriptomic studies and exploration of plant signalling pathways using mutants could be developed for different stages of plant development to better characterize plant response to the presence of earthworms.

A hypothesis has been put forward that the activity of earthworms has a positive impact on plant growth through SM released in the soil. However, the literature is composed of many "chapters" (reported in Table 1) relying either on changes in the soil microbial community, an increase or decrease of SM or modifications in plant development or immunity. This is mainly due to the numerous scientific expertise required in soil chemistry, microbiology, plant physiology, and soil ecology. Therefore, nowadays there is no single study integrating all the chapters in a complete story. 
TABLE 1 | Studies showing the effects of earthworms on plants under controlled conditions

\begin{tabular}{|c|c|c|c|c|c|c|c|}
\hline $\begin{array}{l}\text { Earthworm } \\
\text { species }\end{array}$ & $\begin{array}{l}\text { Functional } \\
\text { group }\end{array}$ & $\begin{array}{l}\text { Area of } \\
\text { influence }\end{array}$ & $\begin{array}{l}\text { Microorganism } \\
\text { species }\end{array}$ & $\begin{array}{l}\text { Signal molecule } \\
\text { released or related }\end{array}$ & $\begin{array}{l}\text { Identification } \\
\text { method }\end{array}$ & $\begin{array}{l}\text { Effect of the } \\
\text { molecule on plants }\end{array}$ & References \\
\hline \multirow[t]{8}{*}{ Eisenia fetida } & Epigeic & Casts & Not reported & IAA and humic acids & $\begin{array}{l}\text { Gas } \\
\text { chromatography } \\
\text { coupled to } \\
\text { masses }\end{array}$ & $\begin{array}{l}\text { Growth of corn } \\
\text { seedling root (Zea } \\
\text { mays) }\end{array}$ & $\begin{array}{l}\text { Canellas } \\
\text { et al., } 2002\end{array}$ \\
\hline & & & & IAA & Not reported & Growth regulator & $\begin{array}{l}\text { Arancon } \\
\text { et al., } 2006\end{array}$ \\
\hline & & & & Humic acids & & $\begin{array}{l}\text { Increased the } \\
\text { development of flowers } \\
\text { and fruits in peppers }\end{array}$ & \\
\hline & & Casts & $\begin{array}{l}\text { Pseudomonas aeruginosa, P. monteilii, P. fluorescens, } \\
\text { Bacillus pumilis, B. subtilis, B. flexus, Microbacterium } \\
\text { schleiferi, Acinetobacter calcoaceticus, A. baumannii, A. junii, } \\
\text { A. schindleri, Stenotrophomonas maltophilia and } \\
\text { Enterobacter cloacae }\end{array}$ & IAA & $\begin{array}{l}\text { Colorimetric } \\
\text { method }\end{array}$ & Growth regulator & $\begin{array}{l}\text { Pathma and } \\
\text { Sakthivel, } \\
2013\end{array}$ \\
\hline & & & $\begin{array}{l}\text { Bacillus megaterium, B. thuringiensis, B. amyloliquefaciens, } \\
\text { B. tequilensis, B. licheniformis, B. cereus, B. pumilus, B. } \\
\text { aryabhattai, B. subtilis, B. flexus, B. aquimaris, B. marisflavi, } \\
\text { Microbacterium takaoensis, Acinetobacter calcoaceticus, A. } \\
\text { baumannii, A. junii, A. schindleri, Arthrobacter nicotianae, } \\
\text { Rhodococcus ruber and Enterobacter cloacae }\end{array}$ & $\begin{array}{l}\text { Aminocyclopropeno- } \\
\text { 1-carboxilate (ACC } \\
\text { ethylene precursor) }\end{array}$ & & $\begin{array}{l}\text { Regulator of ethylene } \\
\text { level in plants for } \\
\text { optimal growth }\end{array}$ & \\
\hline & & Casts & Not reported & ABA & $\begin{array}{l}\text { Identified } \\
\text { unequivocally }\end{array}$ & Not reported & $\begin{array}{l}\text { Hernández, } \\
2019\end{array}$ \\
\hline & & & & JA & through & & \\
\hline & & & & SA & $\begin{array}{l}\text { UPLC in a } \\
\text { directed study }\end{array}$ & & \\
\hline $\begin{array}{l}\text { Nicodrilus caliginosus } \\
\text { and Allolobophora } \\
\text { rosea }\end{array}$ & Endogeic & Casts & Not reported & Auxin-like & $\begin{array}{l}\text { Root growth } \\
\text { inhibition test }\end{array}$ & $\begin{array}{l}\text { Root growth in Daucus } \\
\text { carota }\end{array}$ & $\begin{array}{l}\text { Muscolo } \\
\text { et al., } 1999\end{array}$ \\
\hline $\begin{array}{l}\text { Nicodrilus caliginosus } \\
\text { and Allolobophora } \\
\text { rosea }\end{array}$ & & & & $\begin{array}{l}\text { IAA and low } \\
\text { molecular size } \\
\text { humic substances }\end{array}$ & $\begin{array}{l}\text { Enzyme } \\
\text { linked } \\
\text { immuno- } \\
\text { sorbent assay } \\
\text { (ELISA) }\end{array}$ & $\begin{array}{l}\text { Stimulates the uptake } \\
\text { of nitrate by roots and } \\
\text { the accumulation of the } \\
\text { anion at the leaf level in } \\
\text { Zea mays }\end{array}$ & $\begin{array}{l}\text { Quaggiotti } \\
\text { et al., } 2004\end{array}$ \\
\hline $\begin{array}{l}\text { Aporrectodea } \\
\text { caliginosa }\end{array}$ & & & & $\begin{array}{l}\text { Similar to } \\
\text { phytohormone, such } \\
\text { as auxin and } \\
\text { ethylene }\end{array}$ & Not reported & $\begin{array}{l}\text { Increased total } \\
\text { biomass and biomass } \\
\text { production of Lolium } \\
\text { perennial meristem }\end{array}$ & $\begin{array}{l}\text { Puga-Freitas } \\
\text { et al., 2012b }\end{array}$ \\
\hline
\end{tabular}

We highlight the compounds or signal molecules (SM) that, are responsible for the reported effects on plants.

* *ynonym: Aporrectodea caliginosa. ${ }^{*}$ Synonym: Aporrectodea rosea. 


\section{CONCLUSIONS}

Earthworms are known to play a critical role in ecological processes, through their improvement of soil structure, nutrient cycling and plant growth. Evidence also shows that earthworms contribute towards the structuring of soil microbial communities, either directly through their ingestion or indirectly through a priming effect resulting from an increase of available labile substances. However, few investigations have combined data on earthworm -microorganism interactions with studies on soil nutrient cycling, especially on $\mathrm{P}$ cycling, or the production of signal molecules, which prevents us to fully understand the mechanisms underlying the effect of microbial hotspots in the drilosphere on soil functioning. Our hypothesis "the effect of earthworms on nutrient cycling and plant growth is not only a direct effect but it is mainly mediated indirectly, via modifications of the microbial community" is largely verified at the small spatial and short temporal scale (gut, casts, burrows and tunnels).

Earthworms influence microbial biomass and activity in the soil but contrasting results can be found in the literature regarding the direction of this effect. This could be due to the nature of the organic matter earthworms feed on, particularly in the case of epigeic species or the substrate they live in. This could also be linked with experimental conditions, since the most variable effects on microbial abundance were observed in laboratory studies and consistent increases of microbial abundance by endogeic species were observed in the field (Figure 2). However, the effect on microbial communities is less or neutral when the feedstock or the soil they feed on is rich in assimilable organic matter independently of the functional group. Nonetheless, a recurrent result of our review is the relevance of considering earthworm ecological category (epigeic, anecic, or endogeic) to highlight some trends in the effect of earthworms on the structure and function of microbial communities. Complexification of experimental design, with interactions between earthworm ecological groups and the presence of plants should therefore be considered in mesocosm studies in order to better mimic natural conditions and avoid experimental artifacts.

Although there is still no clarity in understanding if earthworms have their own intestinal microbiome or it comes from the soil, most of the information says it comes from the soil. We can however stress on some general patterns: taxa such as Flavobacterium, Actinobacteria, Firmicutes, and $\gamma$-Proteobacteria are consistently reported to be promoted by gut transit and could therefore constitute good indicators for predicting the impact of earthworms on soil processes. The increasing use of Next Generation Sequencing (NGS) technologies in the study of soil microbial communities and their diversity will help to refine our understanding of how earthworms may shape them. Information is also critically needed regarding the role of earthworms as potential drivers of the composition and structure of fungal communities, particularly mycorrhizal fungi because of their direct interaction with plants (Box 1). On the other hand, saprotrophic fungi, like many bacteria, are key drivers of soil biogeochemistry but their roles have been largely neglected especially in their synergistic or antagonist interactions with earthworms.

Earthworms promote the mineralisation of $\mathrm{N}$ and $\mathrm{P}$ and alter microbial functional genes which modifies soil functions. More information is needed to understand which microorganisms and microbial genes are activated by earthworms, especially on the P cycle.

Finally, the consequences of these earthworm-induced changes in soil functioning on plant growth cannot be fully understood without the study of SM, produced either by the earthworms or most likely by microorganisms created by earthworm activity. The involvement of specific microbial taxa in the secretion of these molecules needs to be elucidated and this requires a collaborative effort from disciplines such a metabolomics, microbiology, transcriptomics, and biochemistry in order to unequivocally identify SM in earthworms or in their casts.

To plagiarize Aristotle, earthworms are indeed the intestine of the Earth, with their specific microbiota, which brings us to a large spatial and temporal scale. This intestine is complex to understand because of its dynamics associated with the activity of earthworms, other soil organisms and plant roots. Nevertheless, we have to consider these complex effects of earthworms on microbial communities in order to understand the effect of earthworms on nutrient cycling and plant growth promoting SM and ultimately to predict plant-soil interactions, especially if earthworms ingest hundreds or thousands of tons of substrates or soil per hectare and per year.

\section{AUTHOR CONTRIBUTIONS}

RM-S and RG did the bibliometric data analysis. FR, AD, JG-A, MÁ-J, MB, RM-S, RG, and IB contributed with the writing of different sections. LV and CC gave ideas for the structure and illustrations of the article and reviewed the manuscript. MÁ-J and MB designed and produced the illustrations. $\mathrm{MB}$ gave constructive suggestions throughout the work to organise the manuscript. FR and IB coordinated the work and integrated and edited the different sections of this article.

\section{ACKNOWLEDGMENTS}

We would like to thank the Consejo Nacional de Ciencia y Tecnología for their financial support (CONACYT, Project 257819) and the scholarship granted to RM-S and MÁ-J. We are grateful to Martin de los Santos for his help in formatting the document and to Judy Shirley for revising the language of this manuscript. We would also like to acknowledge the editors of this issue for giving us the opportunity to be part of it. 


\section{REFERENCES}

Abail, Z., Sampedro, L., and Whalen, J. K. (2017). Short-term carbon mineralization from endogeic earthworm casts as influenced by properties of the ingested soil material. Appl. Soil Ecol. 116, 79-86. doi: 10.1016/j.apsoil.2017.02.022

Aghababaei, F., Raiesi, F., and Hosseinpur, A. (2014). The significant contribution of mycorrhizal fungi and earthworms to maize protection and phytoremediation in Cd-polluted soils. Pedobiologia (Jena). 57, 223-233. doi: 10.1016/j.pedobi.2014.09.004

Aira, M., McNamara, N. P., Piearce, T. G., and Domínguez, J. (2009). Microbial communities of Lumbricus terrestris L. middens: structure, activity, and changes through time in relation to earthworm presence. J. Soils Sediments 9, 54-61. doi: 10.1007/s11368-008-0055-8

Aira, M., Monroy, F., and Domínguez, J. (2005). Ageing effects on nitrogen dynamics and enzyme activities in casts of Aporrectodea caliginosa (Lumbricidae). Pedobiologia 49, 467-473. doi: 10.1016/j.pedobi.2005.07.003

Aira, M., Monroy, F., and Dominguez, J. (2006). Eisenia fetida (Oligochaeta, Lumbricidae) activates fungal growth, triggering cellulose decomposition during vermicomposting. Microb. Ecol. 52, 738-747. doi: $10.1007 / \mathrm{s} 00248-006-9109-\mathrm{x}$

Aira, M., Monroy, F., and Domínguez, J. (2007). Eisenia fetida (Oligochaeta: Lumbricidae) modifies the structure and physiological capabilities of microbial communities improving carbon mineralization during vermicomposting of pig manure. Microb. Ecol. 54, 662-671. doi: 10.1007/s00248-007-9223-4

Aira, M., Monroy, F., Domínguez, J., and Mato, S. (2002). How earthworm density affects microbial biomass and activity in pig manure. Eur. J. Soil Biol. 38, 7-10. doi: 10.1016/S1164-5563(01)01116-5

Aira, M., Olcina, J., Pérez-Losada, M., and Domínguez, J. (2016). Characterization of the bacterial communities of casts from Eisenia andrei fed with different substrates. Appl. Soil Ecol. 98, 103-111. doi: 10.1016/j.apsoil.2015.10.002

Andriuzzi, W. S., Ngo, P. T., Geisen, S., Keith, A. M., Dumack, K., Bolger, T., et al. (2016). Organic matter composition and the protist and nematode communities around anecic earthworm burrows. Biol Fertil Soils 52, 91-100. doi: 10.1007/s00374-015-1056-6

Arancon, N. Q., Edwards, C. A., Lee, S., and Byrne, R. (2006). Effects of humic acids from vermicomposts on plant growth. Eur. J. Soil Biol. 42, S65-S69. doi: 10.1016/j.ejsobi.2006.06.004

Araujo, Y., Luizão, F. J., and Barros, E. (2004). Effect of earthworm addition on soil nitrogen availability, microbial biomass and litter decomposition in mesocosms. Biol. Fertil. Soils 39, 146-152. doi: 10.1007/s00374-003-0696-0

Athmann, M., Kautz, T., Banfield, C., Bauke, S., Hoang, D. T., Lüsebrink, M., et al. (2017). Six months of $L$. terrestris $L$. activity in root-formed biopores increases nutrient availability, microbial biomass and enzyme activity. Appl. Soil Ecol. 120, 135-142. doi: 10.1016/j.apsoil.2017.08.015

Baker, G. (2007). Differences in nitrogen release from surface and incorporated plant residues by two endogeic species of earthworms (Lumbricidae) in a red-brown earth soil in southern Australia. Eur. J. Soil Biol. 43, S165-S170. doi: 10.1016/j.ejsobi.2007.08.037

Barois, I. (1987). Interactions Entre les vers de Terre Geophages Tropicaux et la Microflore du Sol pour L'exploitation de la Matière Organique du Sol. Doctoral thesis in Sciences Biologiques Fondamentales et Appliquees, Psychologie, Université Pierre et Marie Curie, Paris, France.

Barois, I., and Lavelle, P. (1986). Changes in respiration rate and some physicochemical properties of a tropical soil during transit through Pontoscolex corethrurus (Glossoscolecidae, Oligochaeta). Soil Biol. Biochem. 18, 539-541. doi: 10.1016/0038-0717(86)90012-X

Barois, I., Verdier, B., Kaiser, P., Mariotti, A., Rangel, P., and Lavelle, P. (1987). "Influence of the tropical earthworm Pontoscolex corethrurus (Glossoscolecidae) on the fixation and mineralization of nitrogen," in On Earthworms, eds P. Omodeo and A. M. Bonvicini (Bologna: Mucchi), 151-158.

Bernard, L., Chapuis-Lardy, L., Razafimbelo, T., Razafindrakoto, M., Pablo, A. L., Legname, E., et al. (2012). Endogeic earthworms shape bacterial functional communities and affect organic matter mineralization in a tropical soil. ISME J. 6, 213-222. doi: 10.1038/ismej.2011.87

Bertrand, M., Barot, S., Blouin, M., Whalen, J., de Oliveira, T., and Estrade, J. R. (2015). Earthworm services for cropping systems. A review. Agron. Sustain. Dev. 35, 553-567. doi: 10.1007/s13593-014-0269-7
Binet, F., Fayolle, L., Pussard, M., Crawford, J. J., Traina, S. J., and Tuovinen, O. H. (1998). Significance of earthworms in stimulating soil microbial activity. Biol. Fertil. Soils 27, 79-84. doi: 10.1007/s003740050403

Bloemberg, G. V., and Lugtenberg, B. J. (2001). Molecular basis of plant growth promotion and biocontrol by rhizobacteria. Curr. Opin. Plant Biol. 4, 343-350. doi: 10.1016/S1369-5266(00)00183-7

Blouin, M., Barot, S., and Lavelle, P. (2006). Earthworms (Millsonia anomala, Megascolecidae) do not increase rice growth through enhanced nitrogen mineralization. Soil Biol. Biochem. 38, 2063-2068. doi: 10.1016/j.soilbio.2005.12.023

Blouin, M., Hodson, M. E., Delgado, E., Baker, G., Brussaard, L., Butt, K. R., et al. (2013). A review of earthworm impact on soil function and ecosystem services. Eur. J. Soil Biol. 64, 161-182. doi: 10.1111/ejss.12025

Bouché, M. B. (1977). "Stratégies lombriciennes," in Soil Organisms as Components of Ecosystems, eds U. Lohm and T. Persson (Stockholm: Ecological Bulletin), 122-132.

Braga, L. P., Yoshiura, C. A., Borges, C. D., Horn, M. A., Brown, G. G., Drake, H. L., et al. (2016). Disentangling the influence of earthworms in sugarcane rhizosphere. Sci. Rep. 6, 38923. doi: 10.1038/srep38923

Bray, N., Kao-Kniffin, J., Frey, S. D., Fahey, T., and Wickings, K. (2019). Soil Macroinvertebrate Presence Alters Microbial Community Composition and Activity in the Rhizosphere. Front. Microbiol. 10, 256. doi: $10.3389 /$ fmicb. 2019.00256

Brito-Vega, H., and Espinosa-Victoria, D. (2009). Bacterial diversity in the digestive tract of earthworms (Oligochaeta). J. Biol. Sci. 9, 192-199. doi: $10.3923 /$ jbs.2009.192.199

Brown, G. G. (1995). How do earthworms affect microfloral and faunal community diversity? Plant Soil. 170, 209-231. doi: 10.1007/BF02183068

Brown, G. G., Barois, I., and Lavelle, P. (2000). Regulation of soil organic matter dynamics and microbial activity in the drilosphere and the role of interactions with other edaphic functional domains. Eur. J. Soil Biol. 36, 1-23. doi: 10.1016/S1164-5563(00)01062-1

Brown, G. G., Pashanasi, B., Villenave, C., Patrón, J. C., Senapati, K. B., Giri, S., et al. (1999). "Effects of earthworms on plant production in the Tropics", in Earthworm Management in Tropical Agroecosystems, eds P. Lavelle, L. Brussaard, and P. Hendrix (CABI Publishing), 87-147.

Byzov, B. A., Tikhonov, V. V., Nechitailo, T., Yu., Deminc, V. V., and Zvyagintsev, D. G. (2015). Taxonomic Composition and Physiological and Biochemical Properties of Bacteria in the Digestive Tracts of Earthworms. Eurasian Soil Sci. 48, 268-275. doi: 10.1134/S1064229315030035

Canellas, L. P., Olivares, F. L., Okorokova-Façanha, A. L., and Façanha, A. R. (2002). Humic acids isolated from earthworm compost enhance root elongation, lateral root emergence, and plasma membrane $\mathrm{H}^{+}$-ATP ase activity in maize roots. Plant Physiol. 130, 1951-1957. doi: 10.1104/pp.007088

Cao, J., Huang, Y., and Wang, C. (2015a). Rhizosphere interactions between earthworms (Eisenia fetida) and arbuscular mycorrhizal fungus (Funneliformis mosseae) promote utilization efficiency of phytate phosphorus in maize. Appl. Soil Ecol. 94, 30-39. doi: 10.1016/j.apsoil.2015.05.001

Cao, J., Ji, D., and Wang, C. (2015b). Interaction between earthworms and arbuscular mycorrhizal fungi on the degradation of oxytetracycline in soils. Soil Biol. Biochem. 90, 283-292. doi: 10.1016/j.soilbio.2015.08.020

Cao, J., Wang, C., Dou, Z., Liu, M., and Ji, D. (2018). Hyphospheric impacts of earthworms and arbuscular mycorrhizal fungus on soil bacterial community to promote oxytetracycline degradation. J. Haz. Mat. 341, 346-354. doi: 10.1016/j.jhazmat.2017.07.038

Cao, J., Wang, C., and Huang, Y. (2015c). Interactive impacts of earthworms (Eisenia fetida) and arbuscular mycorrhizal fungi (Funneliformis mosseae) on the bioavailability of calcium phosphates. Plant Soil 396, 45-57. doi: 10.1007/s11104-015-2588-0

Cao, J., Wang, C., and Ji, D. (2016). Improvement of the soil nitrogen content and maize growth by earthworms and arbuscular mycorrhizal fungi in soils polluted by oxytetracycline. Sci. Tot. Environ. 571, 926-934. doi: 10.1016/j.scitotenv.2016.07.077

Chang, C-H., Szlavecz, K., and Buyer, J. S. (2016). Species- specific of earthworms on microbial communities and the fate of litter- derived carbon. Soil Biol. Biochem. 100, 129-139. doi: 10.1016/j.soilbio.2016.06.004

Chapuis-Lardy, L., Brossard, M., Lavelle, P., and Schouller, E. (1998). Phosphorus transformations in a Ferralsol through ingestion by Pontoscolex 
corethrurus, a geophagous earthworm. Eur. J. Soil Biol. 34, 61-67. doi: 10.1016/S1164-5563(99)90002-X

Chapuis-Lardy, L. A., Brauman, L., Bernard, A. L., Pablo, J., Toucet, M. J., Mano, L., et al. (2010). Effect of the endogeic earthworm Pontoscolex corethrurus on the microbial structure and activity related to $\mathrm{CO}_{2}$ and $\mathrm{N}_{2} \mathrm{O}$ fluxes from a tropical soil (Madagascar). Appl. Soil Ecol. 45, 201-208. doi: 10.1016/j.apsoil.2010.04.006

Clause, J., Barot, S., Richard, B., Decaëns, T., and Forey, E. (2014). The interactions between soil type and earthworm species determine the properties of earthworm casts. Appl. Soil Ecol. 83, 149-158. doi: 10.1016/j.apsoil.2013.12.006

Coq, S., Barthès, B. G., Oliver, R., Rabary, B., and Blanchart, E. (2007). Earthworm activity affects soil aggregation and organic matter dynamics according to the quality and localization of crop residues-an experimental study (Madagascar). Soil Biol. Biochem. 39, 2119-2128. doi: 10.1016/j.soilbio.2007.03.019

Curry, J. P., and Schmidt, O. (2007). The feeding ecology of earthworms - A review. Pedobiologia 50, 463-477. doi: 10.1016/j.pedobi.2006.09.001

de Menezes, A. B., Prendergast-Miller, M. T., Macdonald, L. M., Toscas, P., Baker, G., Farrell, M., et al. (2018). Earthworm-induced shifts in microbial diversity in soils with rare versus established invasive earthworm populations. FEMS Microbiol. Ecol. 94:fiy051. doi: 10.1093/femsec/fiy051

Decaëns, T., Rangel, A. F., Asakawa, N., and Thomas, R. J. (1999). Carbon and nitrogen dynamics in ageing earthworm casts in grasslands of the eastern plains of Colombia. Biol. Fert. Soils 30, 20-28. doi: 10.1007/s003740050582

Deeb, M., Desjardins, T., Podwojewski, P., Pando, A., Blouin, M., and Lerch, T. Z. (2017). Interactive effects of compost, plants and earthworms on the aggregations of constructed Technosols. Geoderma 305, 305-313. doi: 10.1016/j.geoderma.2017.06.014

Dempsey, M. A., Fisk, M. C., Yavitt, J. B., Fahey, T. J., and Balser, T. C. (2013). Exotic earthworms alter soil microbial community composition and function. Soil Biol. Biochem. 67, 263-270. doi: 10.1016/j.soilbio.2013.09.009

Depkat-Jakob, P. S., Hilgarth, M., Horn, M. A., and Drake, H. L. (2010). Effect of earthworm feeding guilds on ingested dissimilatory nitrate reducers and denitrifiers in the alimentary canal of the earthworm. Appl. Environ. Microbiol. 76, 6205-6214. doi: 10.1128/AEM.01373-10

Devliegher, W., and Verstraete, W. (1997). Microorganisms and soil physicochemical conditions in the drilosphere of Lumbricus terrestris. Soil Biol. Biochem. 29, 1721-1729. doi: 10.1016/S0038-0717(97)00068-0

Domínguez, J., Bohlen, P. J., and Parmelee, R. W. (2004). Earthworms increase nitrogen leaching to greater soil depths in row crop agroecosystems. Ecosystems 7, 672-685. doi: 10.1007/s10021-004-0150-7

Drake, H. L., and Horn, M. A. (2007). As the worm turns: the earthworm gut as a transient habitat for soil microbial biomes. Annu. Rev. Microbiol. 61, 169-189. doi: 10.1146/annurev.micro.61.080706.093139

Egert, M., Marhan, S., Wagner, B., Scheu, S., and Friedrich, M. W. (2004). Molecular profiling of $16 \mathrm{~S}$ rRNA genes reveals diet-related differences of microbial communities in soil, gut, and casts of Lumbricus terrestris L. (Oligochaeta: Lumbricidae). FEMS Microbiol. Ecol. 48, 187-197. doi: 10.1016/j.femsec.2004.01.007

Fjøsne, T., Myromslien, F. D., Wilson, R. C., and Rudi, K. (2018). Earthworms are associated with subpopulations of Gammaproteobacteria irrespective of the total soil microbiota composition and stability. FEMS Microbiol. Lett. 365:fny071. doi: 10.1093/femsle/fny071

Fonte, S. J., and Six, J. (2010). Earthworms and litter management contributions to ecosystem services in a tropical agroforestry system. Ecol. Appl. 20, 1061-1073. doi: 10.1890/09-0795.1

Fujii, K., Ikeda, K., and Yoshida, S. (2012). Isolation and characterization of aerobic microorganisms with cellulolytic activity in the gut of endogeic earthworms. Int. Microbiol. 15, 121-130. doi: 10.2436/20.1501.01.165

Furlong, M. A., Singleton, D. R., Coleman, D. C., and Whitman, W. B. (2002). Molecular and culture-based analyses of prokaryotic communities from an agricultural soil and the burrows and casts of the earthworm Lumbricus rubellus. Appl. Environ. Microbiol. 68, 1265-1279. doi: 10.1128/AEM.68.3.1265-1279.2002

Gange, A. C. (1993). Translocation of mycorrhizal fungi by earthworms during early succession. Soil Biol. Biochem. 25, 1021-1026. doi: 10.1016/0038-0717(93)90149-6

Gange, A. C., and Brown, V. K. (2002). "Actions and interactions of soil invertebrates and arbuscular mycorrhizal fungi in affecting the structure of plant communities," in Mycorrhizal Ecology, eds M. G. A. van der Heijden and I. R. Sanders I. R. Mycorrhizal Ecology. Ecological Studies (Analysis and Synthesis), Vol. 157. (Heidelberg: Springer), 321-344.

Gómez-Brandón, M., Lores, M., and Domínguez, J. (2012). Species-specific effects of epigeic earthworms on microbial community structure during first stages of decomposition of organic matter. PLoS ONE 7:E31895. doi: 10.1371/journal.pone.0031895

Gong, X., Jiang, Y., Zheng, Y., Chen, X., Li, H., Hu, F., et al. (2018). Earthworms differentially modify the microbiome of arable soils varying in residue management. Soil Biol. Biochem. 121, 120-129. doi: 10.1016/j.soilbio.2018.03.011

González, G., and Zou, X. (1999). Earthworm influence on N availability and the growth of Cecropia schreberiana in tropical pastures and forest soils. Pedobiologia 43, 824-829.

González, O., Ortíz-Castro, R., Díaz-Pérez, C., Díaz-Pérez, A. L., Magaña-Dueñas, V., López-Bucio, J., et al. (2017). Non-ribosomal peptide synthases from Pseudomonas aeruginosa play a role in cyclodipeptide biosynthesis, quorumsensing regulation, and root development in a plant host. Microb. Ecol. 73, 616-629. doi: 10.1007/s00248-016-0896-4

Gopal, M., Bhute, S. S., Gupta, A., Prabhu, S. R., Thomas, G. V., Whitman, W. B., et al. (2017). Changes in structure and function of bacterial communities during coconut leaf vermicomposting. Antonie Leeuwenhoek 110, 1339-1355. doi: 10.1007/s10482-017-0894-7

Gormsen, D., Olsson, P. A., and Hedlund, K. (2004). The influence of collembolans and earthworms on AM fungal mycelium. Appl. Soil Ecol. 27, 211-220. doi: 10.1016/j.apsoil.2004.06.001

Groffman, P. M., Fahey, T. J., Fisk, M. C., Yavitt, J. B., Sherman, R. E., Bohlen, P. J., et al. (2015). Earthworms increase soil microbial biomass carrying capacity and nitrogen retention in northern hardwood forests. Soil Biol. Biochem. 87, 51-58. doi: 10.1016/j.soilbio.2015.03.025

Harinikumar, K. M., and Bagyaraj, D. J. (1994). Potential of earthworms, ants, millipedes and termites for dissemination of vesicular-arbuscular mycorrhizal fungi in soil. Biol. Fert. Soil 18, 115-118. doi: 10.1007/BF00336456

Hättenschwiler, S., and Gasser, P. (2005). Soil animals alter plant litter diversity effects on decomposition. Proc. Natl. Acad. Sci. U.S.A. 102, 1519-1524. doi: 10.1073/pnas.0404977102

He, X., Chen, Y., Liu, S., Gunina, A., Wang, X., Chen, W., et al. (2018). Cooperation of earthworm and arbuscular mycorrhizae enhanced plant $\mathrm{N}$ uptake by balancing absorption and supply of ammonia. Soil Biol. Biochem. 116, 351-359. doi: 10.1016/j.soilbio.2017.10.038

Hernández, E. (2019). "Estandarización de la obtención y caracterización de un extracto acuoso de lombricomposta y su efecto en la germinación de Hemileia vastatrix," En: El Extracto Acuoso de Lombricomposta: Generalidades, Caracterización y Potencial Alternativa Para el Control Biológico de Hemileia vastatrix, Master thesis, Instituto de Ecología, A.C., Xalapa, México.

Hoang, D. T., Pausch, J., Razavi, B. S., Kuzyakova, I., Banfield, C. C., and Kuzyakov, Y. (2016). Hotspots of microbial activity induced by earthworm burrows, old root channels, and their combination in subsoil. Biol. Fert. Soils. 52, 1105-1119. doi: 10.1007/s00374-016-1148-y

Hoeffner, K., Monard, C., Santonja, M., and Cluzeau, D. (2018). Feeding behaviour of epi-anecic earthworm species and their impacts on soil microbial communities. Soil Biol. Biochem. 125, 1-9. doi: 10.1016/j.soilbio. 2018.06.017

Hong, S. W., Lee, J. S., and Chung, K. S. (2011). Effect of enzyme producing microorganisms on the biomass of epigeic earthworms (Eisenia fetida) in vermicompost. Bioresour. Technol. 102, 6344-6347. doi: 10.1016/j.biortech.2011.02.096

Horn, M. A., Drake, H. L., and Schramm, A. (2006). Nitrous oxide reductase genes (nosZ) of denitrifying microbial populations in soil and the earthworm gut are phylogenetically similar. Appl. Environ. Microbiol. 72, 1019-1026. doi: 10.1128/AEM.72.2.1019-1026.2006

Horn, M. A., Schramm, A., and Drake, H. L. (2003). The earthworm gut: an ideal habitat for ingested $\mathrm{N}_{2} \mathrm{O}$-producing microorganisms. Appl. Environ. Microbiol. 69, 1662-1669. doi: 10.1128/AEM.69.3.1662-1669.2003

Hosseini Bai, S., Reverchon, F., Xu, C. Y., Xu, Z., Blumfield, T. J., Zhao, H., et al. (2015). Wood biochar increases nitrogen retention in field settings mainly through abiotic processes. Soil Biol. Biochem. 90, 232-240. doi: 10.1016/j.soilbio.2015.08.007 
Ihssen, J., Horn, M. A., Matthies, C., Gössner, A., Schramm, A., and Drake, H. L. (2003). $\mathrm{N}_{2} \mathrm{O}$-producing microorganisms in the gut of the earthworm Aporrectodea caliginosa are indicative of ingested soil bacteria. Appl. Environ. Microbiol. 69, 1655-1661. doi: 10.1128/AEM.69.3.1655-1661.2003

Jenkinson, D. S. (1966). The priming action. J. Appl. Radiat. Isotopes Suppl. 199-208.

Jiménez, J. J., Cepeda, A., Decaëns, T., Oberson, A., and Friesen, D. K. (2003). Phosphorus fractions and dynamics in surface earthworm casts under native and improved grasslands in a Colombian savanna Oxisol. Soil Biol. Biochem. 35, 715-727. doi: 10.1016/S0038-0717(03)00090-7

Jones, C. G., Lawton, J. H., and Shachak, M. (1994). Organisms as ecosystem engineers. Oikos 69:373-386. doi: 10.2307/3545850

Kandeler, E., Deiglmayr, K., Tscherko, D., Bru, D., and Philippot, L. (2006). Abundance of narG, nirS, nirK, and nos Z genes of denitrifying bacteria during primary successions of a glacier foreland. Appl. Environ. Microbiol. 72, 5957-5962. doi: 10.1128/AEM.00439-06

Karsten, G. R., and Drake, H. L. (1995). Comparative assessment of the aerobic and anaerobic microfloras of earthworm guts and forest soils. Appl. Environ. Microbiol. 61, 1039-1044.

Khomyakov, N. V., Kharin, S. A., Nechitailo, T. Y., Golyshin, P. N., Kurakov, A. V., Byzov, B. A., et al. (2007). Reaction of microorganisms to the effects of the digestive fluid of earthworms. Microbiol. 76, 45-54. doi: 10.1134/S0026261707010079

Kim, Y. N., Robinson, B., Lee, K. A., Boyer, S., and Dickinson, N. (2017). Interactions between earthworm burrowing, growth of a leguminous shrub and nitrogen cycling in a former agricultural soil. Appl. Soil Ecol. 110, 79-87. doi: 10.1016/j.apsoil.2016.10.011

König, H. (2006). Bacillus species in the intestine of termites and other soil invertebrates. J. Appl. Microbiol. 101, 620-627. doi: 10.1111/j.1365-2672.2006.02914.x

Koubová, A., Chronáková, A., PiŽl, V., Sánchez-Monedero, M. A., and Elhottová, D. (2015). The effects of earthworms Eisenia spp. on microbial community are habitat dependent. Eur. J. Soil Biol. 68, 42-55. doi: 10.1016/j.ejsobi. 2015.03.004

Kuczak, C. N., Fernandes, E. C. M., Lehmann, J., Rondon, M. A., and Luizão, F. J. (2006). Inorganic and organic phosphorus pools in earthworm casts (Glossoscolecidae) and a Brazilian rainforest Oxisol. Soil Biol. Biochem. 38, 553-560. doi: 10.1016/j.soilbio.2005.06.007

Kuzyakov, Y., and Blagodatskaya, E. (2015). Microbial hotspots and hot moments in soil: concept and review. Soil Biol. Biochem. 83, 184-199. doi: 10.1016/j.soilbio.2015.01.025

Kuzyakov, Y., Friedel, J. K., and Stahr, K. (2000). Review of mechanisms and quantification of priming effects. Soil Biol. Biochem. 32, 1485-1498. doi: 10.1016/S0038-0717(00)00084-5

Laossi, K. R., Decaëns, T., Jouquet, P., and Barot, S. (2010). Can we predict how earthworm effects on plant growth vary with soil properties? Appl Environ Soil Sci. 784342:6. doi: 10.1155/2010/784342

Lattaud, C., Locati, S., Mora, P., and Rouland, C. (1997). Origin and activities of glycolytic enzymes in the gut of the tropical geophagous earthworm Millsonia anomala from Lamto (Côte d'Ivoire). Pedobiologia 41, 242-251.

Lattaud, C., Locati, S., Mora, P., Rouland, C., and Lavelle, P. (1998). The diversity of digestive systems in tropical geophageous earthworms. Appl. Soil Ecol. 9, 189-195. doi: 10.1016/S0929-1393(98)00074-2

Lavelle, P. (1981). Stratégies de reproduction chez les vers de terre. Acta Oecol-Oec. Gen. 2, 117-133.

Lavelle, P. (2002). Functional domains in soils. Ecol. Res. 17, 441-450. doi: 10.1046/j.1440-1703.2002.00509.x

Lavelle, P., Bignell, D., Lepage, M., Wolters, V., Roger, P., Ineson, P., et al. (1997). Soil function in a changing world: the role of invertebrate ecosystem engineers. Eur. J. Soil Biol. 33, 159-193.

Lavelle, P., Lattaud, C., Trigo, D., and Barois, I. (1995). Mutualism and biodiversity in soils. Plant Soil 170, 23-33. doi: 10.1007/BF02183052

Lavelle, P., Melendez, G., Pashanasi, B., and Schaefer, R. (1992). Nitrogen mineralization and reorganization in casts of the geophagous tropical earthworm Pontoscolex corethrurus (Glossoscolecidae). Biol. Fertil. Soils 14, 49-53. doi: 10.1007/bf00336302

Lavelle, P., Pashanasi, B., Charpentier, F. C. G., Rossi, J. P., Derouard, L., André, J., et al. (1998). "Large-scale effect of earthworms on soil organic matter and nutrient dynamics," in Earthworm Ecology, ed C. A. Edwards (Boca Raton, FL: St. Lucie Press), 103-122.

Lavelle, P., Spain, A., Blouin, M., Brown, G., Decaëns, T., Grimaldi, M., et al. (2016). Ecosystem engineers in a self-organized soil: a review of concepts and future research questions. Soil Sci. 181, 91-109. doi: 10.1097/SS.0000000000000155

Lawton, J. H., and Jones, C. G. (1995). "Linking species and ecosystems: organisms as ecosystem engineers," in Linking Species and Ecosystems, eds C. G. Jones and J. H. Lawton (London: Chapman and Hall), 141-158.

Lee, K. E. (1985). Earthworms Their Ecology and Relationships With Soils and Land Use. Sydney: Academic Press Inc.

Lee, K. K., Reddy, M. V., Wani, S. P., and Trimurtulu, N. (1996). Vesiculararbuscular mycorrhizal fungi in earthworm casts and surrounding soil in relation to soil management of a semi-arid tropical Alfisol. Appl. Soil Ecol. 3, 177-181. doi: 10.1016/0929-1393(95)00082-8

Li, H., Wang, C., Li, X., Christie, P., Dou, Z., Zhang, J., et al. (2013a). Impact of the earthworm Aporrectodea trapezoides and the arbuscular mycorrhizal fungus Glomus intraradices on N-15 uptake by maize from wheat straw. Biol. Fert. Soils 49, 263-271. doi: 10.1007/s00374-012-0716-z

Li, H., Wang, C., Li, X., and Xiang, D. (2013b). Inoculating maize fields with earthworms (Aporrectodea trapezoides) and an arbuscular mycorrhizal fungus (Rhizophagus intraradices) improves mycorrhizal community structure and increases plant nutrient uptake. Biol. Fert. Soils 49, 1167-1178. doi: 10.1007/s00374-013-0815-5

Li, H., Xiang, D., Wang, C., Li, X., and Lou, Y. (2012). Effects of epigeic earthworm (Eisenia fetida) and arbuscular mycorrhizal fungus (Glomus intraradices) on enzyme activities of a sterilized soil-sand mixture and nutrient uptake by maize. Biol. Fert. Soils 48, 879-887. doi: 10.1007/s00374-012-0679-0

Lipiec, J., Frac, M., Brzezinska, M., Turski, M., and Oszust, K. (2016). Linking microbial enzymatic activities and functional diversity of soil around earthworm burrows and casts. Front. Microbiol. 7:1361. doi: 10.3389/fmicb.2016.01361

Lopez-Hernandez, D., Lavelle, P., Fardeau, J. C., and Nino, M. (1993). Phosphorus transformations in two P-sorption contrasting tropical soils during transit through Pontoscolex corethrurus (Glossoscolecidae: Oligochaeta). Soil Biol. Biochem. 25, 789-792. doi: 10.1016/0038-0717(93) 90124- T

Lubbers, I. M., van Groenigen, K. J., Fonte, S. J., Six, J., Brussaard, L., and van Groenigen, J. W. (2013). Greenhouse-gas emissions from soils increased by earthworms. Nat. Climate Change 3, 187-194. doi: 10.1038/nclimate1692

Ma, L., Xie, Y., Han, Z., Giesy, J. P., and Zhang, X. (2017). Responses of earthworms and microbial communities in their guts to Triclosan. Chemosphere 168, 1194-1202. doi: 10.1016/j.chemosphere.2016.10.079

McDaniel, J. P., Stromberger, M. E., Barbarick, K. A., and Cranshaw, W. (2013). Survival of Aporrectodea caliginosa and its effects on nutrient availability in biosolids amended soil. Appl. Soil Ecol. 71, 1-6. doi: 10.1016/j.apsoil.2013.04.010

McLean, M. A., Migge-Kleian, S., and Parkinson, D. (2006). Earthworm invasions of ecosystems devoid of earthworms: effects on soil microbes. Biol. Invasions 8, 1257-1273. doi: 10.1007/s10530-006-9020-x

Milleret, R., Le Bayon, R. C., Lamy, F., Gobat, J. M. A., and Boivin, P. (2009). Impact of roots, mycorrhizas and earthworms on soil physical properties as assessed by shrinkage analysis. J. Hydrol. 373, 499-507. doi: 10.1016/j.jhydrol.2009.05.013

Muscolo, A., Bovalo, F., Gionfriddo, F., and Nardi, S. (1999). Earthworms humic matter produces auxin-like effects on Daucus carota cell growth and nitrate metabolism. Soil Biol. Biochem. 31, 1303-1311. doi: 10.1016/S0038-0717(99)00049-8

Nebert, L. D., Bloem, J., Lubbers, I. M., and van Groeningen, J. W. (2011). Association of earthworm denitrifier interactions with increased emission of nitrous oxide from soil mesocosms amended with crop residue. Appl. Environ. Microb. 77, 4097-4104. doi: 10.1128/AEM.00033-11

Nechitaylo, T. Y., Yakimov, M. M., Godinho, M., Timmis, K. N., Belogolova, E., Byzov, B. A., et al. (2010). Effect of the earthworms lumbricus terrestris and Aporrectodea caliginosa on bacterial diversity in soil. Microbial Ecol. 59, 574-587. doi: 10.1007/s00248-009-9604-y

Pashanasi, B., Lavelle, P., Alegre, J., and Charpentier, F. (1996). Effect of the endogeic earthworm Pontoscolex corethrurus on soil chemical characteristics 
and plant growth in a low-input tropical agroecosystem. Soil Biol. Biochem. 28, 801-810. doi: 10.1016/0038-0717(96)00018-1

Pathma, J., and Sakthivel, N. (2013). Molecular and functional characterization of bacteria isolated from straw and goat manure based vermicompost. Appl. Soil Ecol. 70, 33-47. doi: 10.1016/j.apsoil.2013.03.011

Patron, J. C., Sanchez, P., Brown, G. C., Brossard, M., Barois, I., and Gutierrez, C. (1999). Phosphorus in soil and Brachiaria decumbens plants as affected by the geophagous earthworm Pontoscolex corethrurus and $\mathrm{P}$ fertilization. Pedobiologia 43, 547-556.

Pattinson, G. S., Smith, S. E., and Doube, B. M. (1997). Earthworm Aporrectodea trapezoides had no effect on the dispersal of a vesicular-arbuscular mycorrhizal fungi, Glomus intraradices. Soil Biol. Biochem. 29, 1079-1088. doi: 10.1016/S0038-0717(97)00005-9

Pieterse, C. M., Leon-Reyes, A., Van der Ent, S., and Van Wees, S. C. (2009). Networking by small-molecule hormones in plant immunity. Nat. Chem. Biol. 5:308. doi: 10.1038/nchembio. 164

Postma-Blaauw, M. B., Bloem, J., Faber, J. H., Van Groenigen, J. W., De Goede, R. G. M., and Brussaard, L. (2006). Earthworm species composition affects the soil bacterial community and net nitrogen mineralization. Pedobiologia 50, 243-256. doi: 10.1016/j.pedobi.2006.02.001

Puga-Freitas, R., Abbad, S., Gigon, A., Garnier-Zarli, E., and Blouin, M. (2012a). Control of cultivable IAA-producing bacteria by the plant Arabidopsis thaliana and the earthworm Aporrectodea caliginosa. Appl. Environ. Soil Sci. 2012:307415. doi: 10.1155/2012/307415

Puga-Freitas, R., Barot, S., Taconnat, L., Renou, J. -P., and Blouin, M. (2012b). Signal molecules mediate the impact of the earthworm Aporrectodea caliginosa on growth, development and defence of the plant Arabidopsis thaliana. PLoS ONE 7:e49504. doi: 10.1371/journal.pone.0049504

Puga-Freitas, R., and Blouin, M. (2015). A review of the effects of soil organisms on plant hormone signalling pathways. Environ. Exp. Bot. 114, 104-116. doi: 10.1016/j.envexpbot.2014.07.006

Pulleman, M. M., Six, J., Uyl, A., Marinissen, J. C. Y., and Jongmans, A. G. (2005). Earthworms and management affect organic matter incorporation and microaggregate formation in agriculture soils. Appl. Soil Ecol. 29, 1-15. doi: 10.1016/j.apsoil.2004.10.003

Quaggiotti, S., Ruperti, B., Pizzeghello, D., Francioso, O., Tugnoli, V., and Nardi, S. (2004). Effect of low molecular size humic substances on nitrate uptake and expression of genes involved in nitrate transport in maize (Zea mays L.). J. Exp. Bot. 55, 803-813. doi: 10.1093/jxb/erh085

Rattray, R. M., Perumbakkam, S., Smith, F., and Craig, A. M. (2010). Microbiomic comparison of the intestine of the earthworm Eisenia fetida fed ergovaline. Curr. Microbiol. 60, 229-235. doi: 10.1007/s00284-009-9530-8

Reddell, P., and Spain, A. V. (1991). Earthworms as vectors of viable propagules of mycorrhizal fungi. Soil Biol. Biochem. 23, 767-774. doi: 10.1016/0038-0717(91)90147-C

Reverchon, F., Bai, S. H., Liu, X., and Blumfield, T. J. (2015). Tree plantation systems influence nitrogen retention and the abundance of nitrogen functional genes in the Solomon Islands. Front. Microbiol. 6:1439. doi: $10.3389 /$ fmicb. 2015.01439

Ribbons, R. R., Kepfer-Rojas, S., Kosawang, C., Hansen, O. K., Ambus, P., McDonald, M., et al. (2018). Context-dependent tree species effects on soil nitrogen transformations and related microbial functional genes. Biogeochemistry 140, 145-160. doi: 10.1007/s10533-018-0480-8

Ros, M. B., Hiemstra, T., van Groenigen, J. W., Chareesri, A., and Koopmans, G. F. (2017). Exploring the pathways of earthworm-induced phosphorus availability. Geoderma 303, 99-109. doi: 10.1016/j.geoderma.2017. 05.012

Sampedro, L., and Whalen, J. K. (2007). Changes in the fatty acid profiles through the digestive tract of the earthworm Lumbricus terrestris L. Appl. Soil Ecol. 35, 226-236. doi: 10.1016/j.apsoil.2006.04.007

Scheu, S. (2003). Effects of earthworms on plant growth: patterns and perspectives. Pedobiologia 47, 846-856. doi: 10.1078/0031-4056-00270

Scheu, S., Schlitt, N., Tiunov, A. V., Newington, J. E., and Jones, H. T. (2002). Effects of the presence and community composition of earthworms on microbial community functioning. Oecologia 133, 254-260. doi: 10.1007/s00442-002-1023-4

Schönholzer, F., Hahn, D., Zarda, B., and Zeyer, J. (2002). Automated image analysis and in situ hybridization as tools to study bacterial populations in food resources, gut and cast of Lumbricus terrestris L. J. Microbiol. Methods 48, 53-68. doi: 10.1016/S0167-7012(01)00345-1

Shan, J., Liu, J., Wang, Y. F., Yan, X. Y., Guo, H. Y., Li, X. Z., et al. (2013). Digestion and residue stabilization of bacterial and fungal cells, protein, peptidoglycan, and chitin by the geophagous earthworm Metaphire guillelmi. Soil Biol. Biochem. 64, 9-17. doi: 10.1016/j.soilbio.2013.03.009

Sheehan, C., Kirwan, L., Connolly, J., and Bolger, T. (2008). The effects of earthworm functional diversity on microbial biomass and the microbial community level physiological profile of soils. Eur. J. Soil Biol. 44, 65-70. doi: 10.1016/j.ejsobi.2007.09.004

Shin, K. H., Yi, H., Chun, J. S., Cha, C. J., Kim, I. S., and Hur, H. G. (2004). Analysis of the anaerobic bacterial community in the earthworm (Eisenia fetida) intestine. J. Appl. Biol. Chem. 47, 147-152.

Shipitalo, J. M., and Le Bayon, R. (2004). "Quantifying the effects of earthworms on soil aggregation and porosity," in Earthworm Ecology, 2nd Edn., ed C. A. Edwards (Boca Raton, FL: CRC Press), 183-200.

Singh, A., Singh, D. P., Tiwari, R., Kumar, K., Singh, R. V., Singh, S., et al. (2015). Taxonomic and functional annotation of gut bacterial communities of Eisenia foetida and Perionyx excavatus. Microbiol. Res. 175, 48-56. doi: 10.1016/j.micres.2015.03.003

Stromberger, M. E., Keith, A. M., and Schmidt, O. (2012). Distinc microbial and faunal communities and translocated carbon in Lumbricus terrestris drilospheres. Soil Biol. Biochem. 46, 153-162. doi: 10.1016/j.soilbio.2011.11.024

Taheri, S., Pelosi, C., and Dupont, L. (2018). Harmful or useful? A case study of the exotic peregrine earthworm morphospecies Pontoscolex corethrurus. Soil Biol. Biochem. 116, 277-289. doi: 10.1016/j.soilbio.2017.10.030

Taiz, L., and Zeiger, E. (eds). (2010). "Gibberellins: regulators of plant height and seed germination," in Plant Physiology ( Sunderland: Sinauer Associates), 583-619.

Thakuria, D., Schmidt, O., Finan, D., Egan, D., and Doohan, F. M. (2010). Gut wall bacteria of earthworms: a natural selection process. ISME J. 4, 357-366. doi: 10.1038/ismej.2009.124

Tiunov, A., Bonkowski, M., Alphei, J., and Scheu, S. (2001). Microflora, protozoa and nematoda in Lumbricus terrestris burrow walls: a laboratory experiment. Pedobiologia 45, 46-60. doi: 10.1078/0031-4056-00067

Toyota, K., and Kimura, M. (2000). Microbial community indigenous to the earthworm Eisenia foetida. Biol. Fertil. Soils 31, 187-190. doi: $10.1007 / \mathrm{s} 003740050644$

Van Groenigen, J. W., Lubbers, I. M., Vos, H. M., Brown, G. G., De Deyn, B. G., and van Groenigen, J. K. (2014). Earthworms increase plant production: a meta-analysis. Sci. Rep. 4:6365. doi: 10.1038/srep06365

Vivas, A., Moreno, B., Garcia-Rodriguez, S., and Benitez, E. (2009). Assessing the impact of composting and vermicomposting on bacterial community size and structure, and microbial functional diversity of an olive-mill waste. Bioresour. Technol. 100, 1319-1326. doi: 10.1016/j.biortech.2008.08.014

Vos, H. M. J., Ros, M. B. H., Koopmans, G. F., and Van Groenigen, J. W. (2014). Do earthworms affect phosphorus availability to grass? A pot experiment. Soil Biol. Biochem. 79, 34-42. doi: 10.1016/j.soilbio.2014.08.018

Wan, J. H., and Wong, M. H. (2004). Effects of earthworm activity and Psolubilizing bacteria on P availability in soil. J. Plant Nutr. Soil Sci. 167, 209-213. doi: 10.1002/jpln.200321252

Wu, J., Zhang, W., Shao, Y., and Fu, S. (2017). Plant-facilitated effects of exotic earthworm Pontoscolex corethrurus on the soil carbon and nitrogen dynamics and soil microbial community in a subtropical field ecosystem. Ecol. Evol. 7, 8709-8718. doi: 10.1002/ece3.3399

Wurst, S., Dugassa-Gobena, D., Langel, R., Bonkowski, M., and Scheu, S. (2004). Combined effects of earthworms and vesicular-arbuscular mycorrhizas on plant and aphid performance. New Phytol. 163, 169-176. doi: $10.1111 /$ j.1469-8137.2004.01106.x

Xiang, D., and Li, H. (2014). Nutrient uptake in mycorrhizal plants - role of earthworms. Acta Agric. Scan. B. 64, 434-441. doi: 10.1080/09064710.2014.920412

Yakushev, A. V., Blagodatsky, S. A., and Byzov, B. A. (2009). The effect of earthworms on the physiological state of the microbial community at vermicomposting. Microbiol. 78, 510-519. doi: 10.1134/S002626170904016X

Yu, J., Hu, F., Huixin, L., and Chunyun, M. (2008). Earthworm (Metaphire guillelmi) effects on rice photosynthates distribution in the plant-soil system. Biol. Fertil. Soils 44, 641-647. doi: 10.1007/s00374-007-0250-6 
Yu, X. Z., Cheng, J. M., and Wong, M. H. (2005). Earthworm-mycorrhiza interaction on Cd uptake and growth of ryegrass. Soil Biol. Biochem. 37, 195-201. doi: 10.1016/j.soilbio.2004.07.029

Zaller, J. G., Heigl, F., Grabmaier, A., Lichtenegger, C., Piller, K., and Allabashi, R. (2011). Earthworm-mycorrhiza interactions can affect the diversity, structure and functioning of establishing model grassland communities. PLoS ONE 6:e29293. doi: 10.1371/journal.pone.0029293

Zhang, B. G., Li, G. T., Shen, T. S., Wang, J. K., and Sun, Z. (2000). Changes in microbial biomass $\mathrm{C}, \mathrm{N}$, and $\mathrm{P}$ and enzyme activities in soil incubated with the earthworms Metaphire guillelmi or Eisenia fetida. Soil Biol. Biochem. 32, 2055-2062. doi: 10.1016/S0038-0717(00) 00111-5

Zhang, W., Cao, J., Zhang, S., and Wang, C. (2016). Effect of earthworms and arbuscular mycorrhizal fungi on the microbial community and maize growth under salt stress. Appl. Soil Ecol. 107, 214-223. doi: 10.1016/j.apsoil. 2016.06.005

Zhang, W., Wang, C., Lu, T., and Zheng, Y. (2018). Cooperation between arbuscular mycorrhizal fungi and earthworms promotes the physiological adaptation of maize under a high salt stress. Plant Soil 423, 125-140. doi: 10.1007/s11104-017-3481-9

Zhong, H., Kim, Y. N., Smith, C., Robinson, B., and Dickinson, N. (2017). Seabird guano and phosphorus fractionation in a rhizosphere with earthworms. Appl. Soil Ecol. 120, 197-205. doi: 10.1016/j.apsoil.2017.08.006

Conflict of Interest Statement: The authors declare that the research was conducted in the absence of any commercial or financial relationships that could be construed as a potential conflict of interest.

Copyright (C) 2019 Medina-Sauza, Álvarez-Jiménez, Delhal, Reverchon, Blouin, Guerrero-Analco, Cerdán, Guevara, Villain and Barois. This is an open-access article distributed under the terms of the Creative Commons Attribution License (CC BY). The use, distribution or reproduction in other forums is permitted, provided the original author(s) and the copyright owner(s) are credited and that the original publication in this journal is cited, in accordance with accepted academic practice. No use, distribution or reproduction is permitted which does not comply with these terms. 